\title{
MULHER NEGRA NA ARENA PORNÔ- ERÓTICA DO PÓS-ABOLIÇÃO CARIOCA: EMBATES ENTRE O FEMININO GENTRIFICADO DO RIO NU E O FEMININO VIVIFICANTE DE GILKA MACHADO
}

\author{
Marina Vieira de Carvalho'
}

\begin{abstract}
Resumo
Essa pesquisa analisa o imaginário pornô-erótico sobre a mulher negra no pós-abolição carioca. Nessa ordem discursiva se confrontaram o que chamamos de "potências pornôeróticas masculinas" - o periódico Rio Nu (1898-1916) - e "potências pornô-eróticas femininas" - a poesia de Gilka Machado. Tais produções, recorrendo a diferenciados significados para as performances de gênero - interseccionados por questões de classe e raça - criaram diferentes tipos ficcionais de mulher na disputa pela construção de uma sensibilidade erótica moderna. A irrupção da poesia erótica de Gilka Machado - mulher, afrodescendente e socioeconomicamente vulnerável -, transgrediu a própria tradição pornô-erótica ao alterar a condição feminina - de objeto para sujeito; bem como ao possibilitar outras representações para mulheres negras e pobres na alvorada da modernidade carioca.
\end{abstract}

Palavras chaves: pornô-erotismo; relações de gênero, raça e classe; Gilka Machado.

\begin{abstract}
This research analyzes the porn-erotic imaginary about the black woman in the postabolition of Rio. In this discursive order we confront what we call "male porn-erotic powers" - the journal Rio Nu (1898-1916) - and "female porn-erotic powers" - the poetry of Gilka Machado. Such productions, using different meanings for gender performances - intersecteds by issues class and race - they created different fictional types of women in the struggle to construct a modern erotic sensibility. The eruption of Gilka Machado's erotic poetry - woman, afrodescendant, and socioeconomically vulnerable -, transgressed the porn-erotic tradition itself by altering the female condition - from object to subject; further transgresses by enabling other representations for black and poor women at the dawn of carioca modernity.
\end{abstract}

Keywords: porn-eroticism; gender, race and class relations; Gilka Machado.

\footnotetext{
${ }^{1}$ Professora do departamento de História da Universidade Federal do Acre e coordenadora da linha de pesquisa "Vulnerabilidades" do Laboratório de Estudos das Diferenças e Desigualdades Sociais (LEDDES / UERJ).
} 


\title{
Introdução
}

\begin{abstract}
Quanto tempo faz que eles contam a nossa história?/ Quanto tempo faz que eles constroem a nossa memória?/ Eu vim pra contar que tão certo como o agora/ eu estarei nas linhas que contam a nossa vitória/ A minha escrivivência transcende a sua teoria/O que tá no seu caderno/ Eu vivo no dia a dia/ representatividade/ é nós por nós/ e ninguém vai falar por mim/ eu tenho a minha voz/ E se a minha voz em algum momento falhar/ Posso te garantir/ tem muita preta pra falar/ Então, deixa que eu conto/ A minha história/ Eu me represento/ Eu recebo minhas glórias/ aprendo com as minhas/ E tão certo como agora/ Eu estarei nas linhas que contam a nossa vitória. (Bia Ferreira)
\end{abstract}

Quanto tempo faz que eles contam a nossa história? A canção de Bia Ferreira apresenta a importância das escrivivências ${ }^{2}$ nos processos de construção de memórias, na relação entre "imagens de controle" e "autodefinição", enfim, na construção de identidades ${ }^{4}$. Denuncia como a escrita da História tradicional silenciou e/ou rebaixou as diversas participações sócio-políticas, culturais, econômicas e simbólicas de mulheres negras como sujeitos históricos. Nesse estudo acompanharemos a construção de dois tipos ficcionais de femininos, materializados por diferentes discursividades pornô-eróticas, atravessados pela colonialidade de gênero ${ }^{5}$. Isto é, esta pesquisa

parte da produção cognitiva da modernidade que conceitualizou a raça como "engendrada" e o gênero como racializado de maneiras particularmente diferenciadas entre europeus europeias / brancos(as) e as pessoas colonizadas/ não-brancas. A raça não é nem mais mítica nem

\footnotetext{
2 Termo aqui problematizado a partir de Conceição Evaristo: "seria escrever a escrita dessa vivência de mulher negra na sociedade brasileira. Eu acho muito difícil a subjetividade de qualquer escritor ou escritora não contaminar a sua escrita. De certa forma, todos fazem uma escrevivência, a partir da escolha temática, do vocabulário que se usa, do enredo a partir de suas vivências e opções. A minha escrevivência e a escrevivência de autoria de mulheres negras se dá contaminada pela nossa condição de mulher negra na sociedade brasileira. Toda minha escrita é contaminada por essa condição. É isso que formata e sustenta o que estou chamando de escrevivência". (EVARISTO, 2017: 26 maio).

3 Patrícia Hills Collins, em: Pensamento feminista negro, apresenta como as mulheres negras são inferiorizadas a partir de imagens depreciativas. "Essas imagens de controle são traçadas para fazer com que o racismo, o sexismo, a pobreza e outras formas de injustiça social pareçam naturais, normais e inevitáveis na vida cotidiana" (COLLINS, 2019: p. 136). Essa posição de "outsider interna" da mulher negra - um Outro invisível - cria uma tensão que pode levar a construção de "autodefinições" apresentadas por Collins como um tipo de "conhecimento construído do 'eu' [que] emerge da luta para substituir as imagens de controle pelo conhecimento autodefinido, considerado pessoalmente importante, um conhecimento muitas vezes essencial para a sobrevivência de mulheres negras" (COLLINS, 2019: 184).

${ }^{4}$ Para Stuart Hall, identidade é: “o ponto de encontro, o ponto de sutura, entre, por um lado, os discursos e as práticas que tentam nos "interpelar", nos falar ou nos convocar para que assumamos lugares como os sujeitos sociais de discursos particulares e, por outro lado, os processos que produzem subjetividades, que nos constroem como sujeitos aos quais se pode 'falar'. As identidades são, pois, pontos de apego temporário às posições-de-sujeito que as práticas discursivas constroem para nós”. (Hall, 2009: 111-112).

${ }^{5}$ A colonialidade de gênero produz hierarquias e desigualdades pela racialização dos corpos, dos sexos e dos próprios gênero "Diferentemente da colonização, a colonialidade do gênero ainda está conosco; é o que permanece na intersecção de gênero/classe/raça como construtos centrais do sistema de poder capitalista mundial" (LUGONES, 2014, p. 939).
} 
mais fictícia que o gênero - ambas são ficções poderosas (LUGONES, 2008: p. 93-94. Livre tradução) ${ }^{6}$.

Gênero e raça são aqui considerados não por um viés biologizante interessado em encontrar quem seria ou não "verdadeiramente" "negro(a)" ou "mestiço(a)" na "complexa miscigenação brasileira", nem mesmo por "fantasias a respeito de 'estoque racial', males ou benefícios da miscigenação etc" (RIOS, 2014)7 ; e sim são operacionalizados como construções sócio-históricas "sistema-mundo capitalista/patriarcal/cristão/moderno/colonial europeu" (Grosfoguel, 2016:17). Aqui, raça e gênero são compreendidos por meio do pensamento feminista decolonial ${ }^{8}$ como ficções sociais criadoras e mantenedoras da colonialidade do poder que classifica as pessoas em termos de raça. Sendo assim, esta pesquisa contribui para a desnaturalização e compreensão de certas dimensões do racismo estrutural por meio da problematização dos embates entre os distintos imaginários de feminino presentes no periódico pornôerótico Rio Nu (1898-1916) e na poesia de Gilka Machado (1893-1980).

Como este estudo problematiza o imaginário social ${ }^{10}$ sobre a mulher negra por meio das ficções pornô-eróticas, a metodologia adotada não é orientada por viés dicotômico interessado em estabelecer a diferença entre a "realidade" e a "ficção" sobre as representações de gênero, raça e classe em tal documentação, e sim a investiga pela

\footnotetext{
6 "parte de la producción cognitiva de la modernidade que ha conceptualizado la raza como 'engenerizada' y al género como racializado de maneras particularmente diferenciadas entre los europeos-as/blancos-as y las gentes colonizadas/no-blancas. La raza no es ni más mítica ni más ficticia que el género -ambos son ficciones poderosas" [original].

${ }^{7}$ As historiadoras Hebe Mattos e Ana Maria Rios analisam o pós-abolição como categoria de análise historiográfica, a qual conta com uma vasta produção em que se destacam temas como: a questão da mestiçagem, a entrada de imigrantes estrangeiros para substituição da mão- de obra, as teorias raciais do período, a marginalização dos afrodescendentes nos caminhos do pós abolição e os distintos significados de cidadania em uma sociedade herdeira da escravidão e da colonização. Sobre o atual estado da categoria, as historiadoras afirmam: "Enquanto historiadores, fomos atormentados por muito tempo sobre fantasias a respeito de 'estoque racial', males ou benefícios da miscigenação etc... exatamente porque passamos muito tempo discutindo as visões das elites a respeito de cidadania, e não a dos "novos cidadãos", os ex-escravos. [...] Cidadania, na compreensão dos novos estudos sobre o pós-abolição, é um conceito essencialmente mutável, e apenas começamos a nos aproximar de uma história que dê conta de suas múltiplas facetas" (RIOS, 2004: 191-192).

${ }^{8} \mathrm{O}$ feminismo decolonial, "a diferencia de las feministas blancas que no se han enfocado en cuestiones de colonialismo, estas teóricas/os sí ven la construcción diferencial del género en términos raciales. [..]el sistema de género moderno, colonial no puede existir sin la colonialidad del poder, ya que la clasificación de la población en términos de raza es una condición necesaria para su posibilidad. (LUGONES, 2014: p.93-99)

${ }^{9}$ As edições digitalizadas do periódico estão disponíveis na Hemeroteca da Biblioteca Nacional, Cf.: http://bndigital.bn.br/acervo-digital/rio-nu/706736 Acesso em: 18. Abr. 2020.

${ }^{10}$ Imaginário é a "criação incessante e essencialmente indeterminada (social-histórica e psíquica) de figuras / formas / imagens, a partir das quais somente é possível falar-se de 'alguma coisa'. Aquilo que denominamos 'realidade' e 'racionalidade' são seus produtos." In: CASTORIADIS, Cornélius. A instituição imaginária da sociedade. Rio de Janeiro: Paz e Terra, 1982,13.
} 
tríade "realidade, fíctício e imaginário" proposta pela noção de fíccionalidade de Wolfgang Iser ${ }^{11}$. Tal metodologia possibilita analisar as materializações dos imaginários sociais na realidade sócio-histórico instituída por meio da orientação ficcional, a partir das quais apresento neste artigo dois diferentes imaginários sobre o feminino, bem como seus correspondentes tipos ficcionais de mulher, ambos atuantes no Rio de Janeiro nas primeiras décadas do século XX.

O pornô-erotismo ${ }^{12}$ moderno, criado pelo chamado iluminismo libertino, nasce transgressivo ao instaurar no imaginário social a decadência moral da nobreza e do clero, tecendo no tecido social certa animalidade torpe daqueles que se apresentavam como superiores, sublimes, puros; transgride por situar a cruz e a coroa na alcova (DARNTON, 1996). No entanto, o aparecimento de escritas pornô-eróticas de mulheres, e, ainda, de escritoras não brancas, ao apresentá-las como sujeitos de sua sexualidade e não como objetos da sexualidade masculina branca - criadora da tradicional narrativa pornô-erótica; ao expor outras possibilidades de representações sexuais, de gênero, raça e classe, criaram potencialidades altamente perturbadoras ao ordenamento social da época, invertendo temas clássicos deste tipo de literatura. Transgredindo, assim, uma tradição literária que já nasceu transgressora tanto em seu contexto histórico, como em relação ao projeto existencial do sujeito moderno ${ }^{13}$.

\footnotetext{
${ }^{11}$ Se o fictício (encenação) e o imaginário fazem parte da antropologia humana, o que diferencia a literatura das

demais ficções da "realidade", é que ela é "a articulação organizada do fíctício e do imaginário" (ISER, 2013:

29). Os textos ficcionais - entendidos aqui como atos intencionais de configuração do imaginário instauram a

possibilidade de manifestação desse imaginário na realidade instituída, transgredindo seus limites prédeterminados, tornando possível (imaginável) o que não era. Tal ficção, ao transgredir os limites estabelecidos

socialmente, apresenta a realidade não como uma estrutura ontológica e definitiva, mas como uma de suas potências tornando imaginável a criação de outras. $C f$ : ISER, 2013.

12 Nesse estudo, os termos eróticos e pornográficos são problematizados sem o julgamento moral que classifica um como sublime (erotismo) e outro como vulgar (pornografia); eles serão apresentados em suas potências na arena sócio-política do Rio de Janeiro do início do século XX, daí a preferência para o termo pornô-erótico.

13 “O pornô-erótico - em seus aspectos significados como baixos, depravados, grotescos - excita por atuar num espaço da existência onde se consagram interditos, como o sexo. Se aceitarmos o convite pornográfico, suspendemos, neste instante, o tabu à liberdade sexual e, por meio da nossa imaginação, nos deleitamos nessa festa, enfim, gozamos com ela. Mas esse gozo é acompanhado de certa angústia, certo constrangimento, uma culpa por ter desfrutado de tal vulgaridade. Nosso ser é posto em questão diante de uma criação pornô-erótica por ela maximizar, de modo direto e efetivo, as impulsões sexuais. Nesse momento não somos mais o indivíduo racional e ordenado, somos o animal que só atende a um chamado: o do prazer erótico. Não raciocinamos: preferimos desfalecer para viver aquela sensação de suspensão do tempo-espaço; o frenesi da ausência de si." In: CARVALHO, Marina Vieira de. Leituras do prazer: a criação pornô-erótica na alvorada da modernidade carioca. Rio de Janeiro: UERJ/IFCH - PPGH, 2018: 18.
} 
A ordem do discurso pornô-erótico não atua num palco homogêneo e harmonioso, ao contrário, ela institui instituindo ${ }^{14}$ uma arena ${ }^{15}$, marcada por antagonismos e alianças. Nessa arena, apresento duas posições, a princípio, antagônicas: as potências pornôeróticas masculinas e as potências pornô-eróticas femininas. Para compor tal arena, para esse artigo escolho o Jornal Rio $\mathrm{Nu}$ para a problematização da discursividade de imaginação masculina; as poesias de Gilka Machado compõem as potências pornôeróticas femininas ${ }^{16}$. Aqui é a política cotidiana, em seu jogo de tática e estratégia. ${ }^{17} \mathrm{~A}$ princípio tais discursos são antagônicos, justamente, por materializarem distintas significações sobre os papeis de gênero, de classe e de raça.

Tratando-se de uma sociedade atravessada pela colonialidade do poder, não é grande a surpresa de constatar que a imaginação pornô-erótica masculina é marcada por uma concepção virilista e racista, na qual a mulher é o grande tema, porém objetificada por uma masculinidade que expressava suas fantasias sobre as mulheres (brancas e negras). Já as escritas femininas encarnam, justamente, o medo masculino: (des)ordenam às performances de gêneros instituídas e, em alguns casos abordados nesse estudo, também transgridem a colonialidade de gênero. Se num momento elas são antagônicas, num outro elas se alinham no mesmo espaço social, pois ambas são marginalizadas por serem pornô-eróticas. Marginalizadas porque instauram transgressões a moralidade

\footnotetext{
${ }^{14}$ Para Castoriadis (1982) as sociedades e os seres humanos são feitos no e pelo imaginário. Cada sociedade se institui instituindo um magma de significações imaginárias sociais, ou seja, se faz fazendo seu modo de existência no mundo. Como não tem uma estrutura determinada e definitiva e sim magmática, em seu fazer cada sociedade se abre as possibilidades de transformação.

${ }^{15}$ Para compreender o político como uma arena, ou seja, um palco de disputas, recorro às considerações de Chantal Moufe. O individualismo e o racionalismo apropriados pelas democracias liberais negam a dimensão conflituosa, os pluralismos e as identidades coletivas que são inerentes às relações políticas. Para Mouffe "Toda ordem política se baseia em alguma forma de exclusão. Sempre existem outras possibilidades, que foram reprimidas e que podem ser reativadas As práticas de articulação por meio das quais se estabelece uma determinada ordem e se determina o significado das instituições sociais são 'práticas hegemônicas'. Toda ordem hegemônica é passível de ser desafiada por práticas anti-hegemônicas, isto é, práticas que tentarão desarticular a ordem existente para instalar outra forma de hegemonia. (MOUFFE, 2015: 17). As ambivalências e conflitos fazem parte das sociabilidades humanas, esvaziar tal tensão da política democrática é esvaziar o político em si. Para Chantal Mouffe, o desafio não é a implementação de um consenso universal, mas sim a criação "de uma vibrante esfera política 'agonística' de contestação, na qual diferentes projetos políticos hegemônicos possam se confrontar" (MOUFFE, 2015: $3)$.

${ }^{16}$ Sobre demais produções pornô-eróticas da Primeira República, tanto potências femininas como masculinas, $C f .:$ CARVALHO, 2018.

${ }^{17}$ Para Certeau, a tática é: "a ação calculada que é determinada pela ausência de um próprio. Ela não tem, portanto, a possibilidade de dar a si mesma um projeto global nem de totalizar o adversário num espaço distinto, visível e objetável. Ela opera golpe por golpe, lance por lance. (...) Em suma, a tática é a arte do fraco." Já estratégia é: "a estratégia postula um lugar suscetível de ser circunscrito como algo próprio e ser a base de onde se podem gerir as relações com uma exterioridade de alvos ou ameaças. (...) toda racionalização 'estratégica' procura em primeiro lugar distinguir de um 'ambiente' um 'próprio', o lugar do poder e do querer próprios. O próprio é a vitória do lugar sobre o tempo. (...) É o domínio do tempo pela fundação de um lugar próprio". In: CERTEAU, 1994: 99/ 100/101.
} 
sociocultural e política ${ }^{18}$, bem como rebaixadas pelo cânone literário e artístico e, ainda, numa escala internacional, são marginalizadas por serem de um país considerado periférico, composto por uma população negra e mestiça.

Essas potências, uma vez lançadas no social-histórico, exigem conflitos e negociações. Eis a arena das potências pornô-eróticas do Rio de Janeiro na alvorada de sua modernidade, em destaque os diferentes tipos ficcionais de mulher e suas intersecções ${ }^{19}$ de raça, classe e gênero.

\section{Potências pornô-eróticas masculinas: o feminino gentrificado}

Comecemos com as potências pornô-eróticas masculinas. Para construção de sua mulher do desejo, seus criadores selecionaram elementos referenciais do social-histórico instituído ${ }^{20}$. Em tais potências, a mulher desejante é, essencialmente, branca. Nessa seleção, a mulher "real" da cidade, afrodescendentes e mestiças da diversidade de cores características da miscigenação, são silenciadas ou depreciadas. Ou seja, a mulher do desejo masculino dos jornais de gênero alegre se constrói pelo avesso da mulher "real", esta atua como a sombra da mulher fictícia. Aqui, os discursos sobre o branqueamento correntes na época são apropriados para a construção de um desejo que se propõe ser imoralmente civilizador:

\footnotetext{
${ }^{18}$ Sobre as críticas à política da Primeira República e à Igreja Católica realizadas pela produção pornôerótica do período, Cf.: CARVALHO, 2018.

19 "A interseccionalidade é uma conceituação do problema que busca capturar as consequências estruturais e dinâmicas da interação entre dois ou mais eixos da subordinação. Ela trata especificamente da forma pela qual o racismo, o patriarcalismo, a opressão de classe e outros sistemas discriminatórios criam desigualdades básicas que estruturam as posições relativas de mulheres, raças, etnias, classes e outras." In: CRENSHAW, Kimberlé Williams. Documento para o encontro de especialistas em aspectos da discriminação racial relativos ao gênero. Revista Estudos Feministas 10, 2002, p. 177.

${ }^{20}$ Para compor os tipos ficcionais de mulher, recorro aos três "atos de fingir" dos textos ficcionais apresentados por Wolfgang Iser. Os atos de fingir se concretizam por três funcionalidades: seleção (acontece quando, na criação ficcional, o autor escolhe elementos pré-existentes do social-histórico para compor sua ficção), combinação (promove a intratextualidade das referenciais textuais, da realidade referida no texto e dos esquemas organizadores do enredo) e autoindicação (apresentação do texto como deliberadamente ficcional, sem compromisso com a verdade conforme outras fícções atuantes e organizadoras do social-histórico). Tais atos se caracterizam pela transgressão, tanto dos elementos do social-histórico instituído (transgressão de seus limites, promoção de novos valores, irrealização do real e de si); quanto do imaginário que, de indeterminado e difuso, se configura pela orientação instaurada pelo fictício e pode, desta forma, ganhar presença na realidade estabelecida. A experiência de reformulação da sociedade instituída e o sentido da leitura permanecem indeterminados, contudo, pois é pelas reações e atitudes do leitor que encontram sua compreensão. Cf.: ISER, 2013.
} 


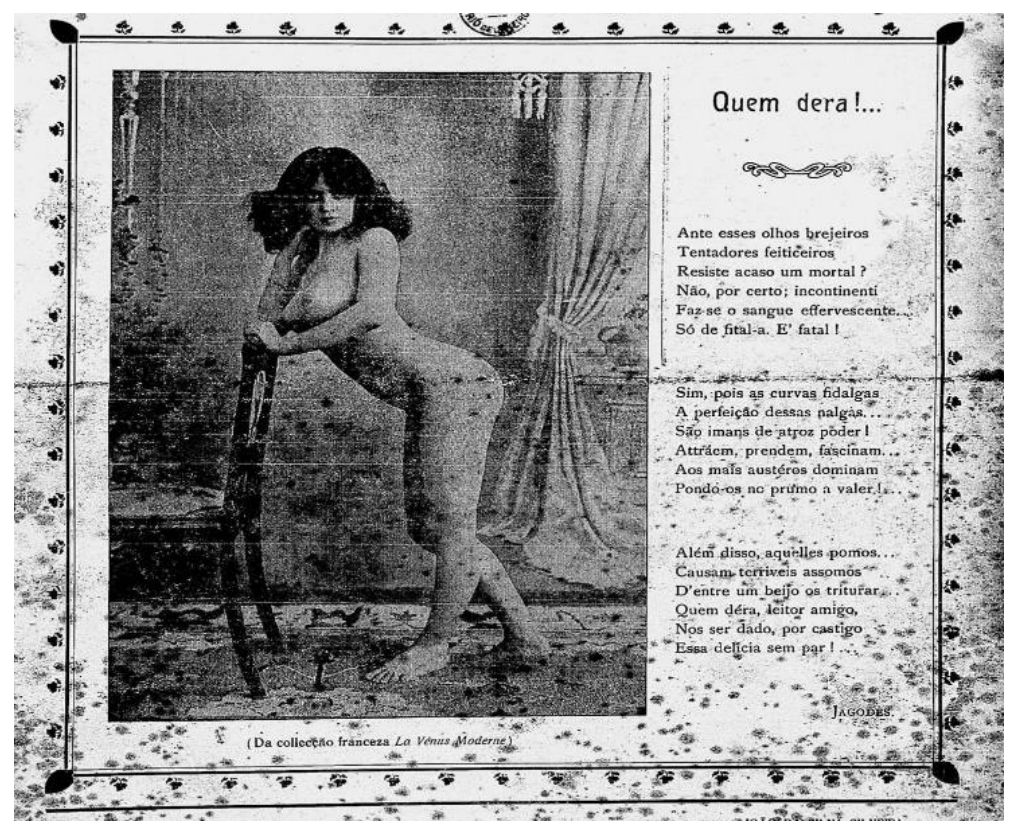

Figura 1: La Vénus Moderne. (Rio Nu, 28.dez.1910)

\section{O Rio $\mathrm{Nu}$ configurou o imaginário ${ }^{21}$ pornô-erótico nessa capa ao selecionar e} combinar imaginários de longa tradição com elementos da sociedade carioca da época. A mulher do desejo é branca e tem uma nacionalidade - ela é francesa -, combinando a nudez do Rio à belle époque imoral. Aqui o leitor precisa se irrealizar ${ }^{22}$ para realizar a ficção apresentada. A legenda informa que a foto é da coleção francesa La Vénus Moderne, ou seja, ela tem uma árvore genealógica que não obedece a historicidade do contexto, pois sua genealogia não é portuguesa, latino-americana, indígena ou africana. Por isso a necessidade de suspender o social histórico instituído para realizar a ficção: sua genealogia é, justamente, o "berço" da civilização da Europa Ocidental: Grécia; sua

\footnotetext{
${ }^{21}$ Nessa pesquisa, trabalho com diferentes tipos de documentos aqui entendidas como um conjunto narrativo extenso, cada qual com sua presença-diferença compreendidas pela noção de ficcionalidade de Wolfgang Iser. O teórico da literatura substitui a dicotomia tradicional entre real e ficção pela tríade "realidade", fictício e imaginário. Para Iser, as ficções - categoria que propomos estender tanto aos registros legíveis quanto aos visíveis - configuram e manifestam o(s)imaginário(s), permitindo assim sua investigação. Cf.: ISER, 2013.

22 "Se irrealizar" se refere ao terceiro ato de fingir, o qual instaura efeitos no leitor. Este se irrealiza para experimentar o imaginário figurado pelo texto fictício: "a representabilidade daquilo que é provocado pelo como se significa que nossas capacidades se põem a serviço desta irrealidade para, no processo de irrealização, transformá-la em realidade" (ISER, 2013: 48). Tal acontecimento produz uma tensão no leitor que corresponde a "um importante achado da psicolinguística: toda expressão verbal é acompanhada pela expectativa da constância de sentido" (ISER, 2013: 49). Dessa forma, diante da tensão de experimentar o imaginário pelo fictício, o leitor, para controlar tal experiência, busca um sentido pela semantização do irreal do texto ficcional. Em outras palavras, o leitor, de forma ativa, procura sanar tal tensão ao reconduzir o acontecimento do imaginário a um sentido que lhe seja conhecido. É nesse momento que se instaura o sentido do texto fictício pelo processo de semantização. Essa transgressão que o como se promove no leitor, a transgressão de si mesmo por sua irrealização, é assimilada por tal busca. Daí a diversidade de "sentidos" que um texto ficcional pode possibilitar pela tríade real, imaginário e fictício, sendo esta sua condição de existência
} 
ancestral é Vênus, deusa do amor, que agora se apresenta dentro da modernidade - é uma Vênus moderna. Ela só se realiza, justamente, pela suspensão das mulheres "reais" da cidade.

Os versos que complementam a imagem fornecem mais pistas sobre o tipo de feminino das potências pornô-eróticas masculinas:

\begin{tabular}{|c|c|}
\hline Ante esses olhos brejeiros & são ímãs de atroz poder! \\
tentadores feiticeiros & Atraem, prendem, fascinam. \\
resiste acaso um mortal? & Aos mais austeros dominam! \\
Não, por certo, incontinente. & Pondo-os no prumo a valer! [...] \\
Faz-se o sangue efervescente... & Quem dera, leitor amigo, \\
Só de fitá-la é Fatal & nos ser dado por castigo \\
A perfeição dessas nalgas & Essa delícia sem par \\
Sim, pois as curvas fidalgas & (Rio Nu, Capa. 28.12.1910) \\
\hline
\end{tabular}

Ela cujos olhos, "tentadores feiticeiros", colocam em xeque o "mortal" homem; ela cuja natureza não é ser racional, mas sim portadora de uma imaginação perigosa porque de natureza misteriosa em harmonia com as qualidades específicas do belo sexo; ela que emprega seus atributos de sedução, que "são ímãs de atroz poder", para seduzir e fascinar não por amor ou paixão ou desejo carnal, mas para dominar até "os mais austeros" dos homens; ou seja, ela é fatal! Aqui o Rio Nu configura o imaginário do maldito feminino oitocentista: les femmes fatales: criação artístico-literária de figuras femininas nascidas para seduzir os homens, não por amá-los e desejá-los, mas por ser de sua natureza, misteriosa e maldita, sentir prazer em levá-los a destruição. As femmes fatales oitocentistas são uma das reações de certa masculinidade amedrontada com o surgimento da Primeira Onda Feminista, temerosa com o desfacelamento da suposta superioridade de sua identidade sexual e de gênero ${ }^{23}$.

Nas potências pornô-eróticas masculinas, o corpo da mulher do desejo é signo e símbolo da modernização da capital do país. A ficção pornô-erótica seleciona e exclui elementos referenciais instituídos: o ausente são as mulheres das camadas populares, as afrodescendentes e a variedade de mestiças; as selecionadas são as mulheres das camadas socioeconomicamente elevadas, brancas, de perfis e comportamentos europeizados. As mulheres das camadas populares foram silenciadas por não serem classificadas como "civilizadas", ao contrário, representavam a herança escravista, a mistura das diferentes etnias vistas como causa da degeneração do povo brasileiro. Elas atuam como o lado escuro dessa mulher do desejo, sendo seu limite, potencializando o estilo corporal e

${ }^{23} C f:$ : GAY, 1988; OLIVEIRA, 2005. 
comportamental de um feminino imaginário do desejo masculino, justamente, por atuarem como seu avesso. Uma refinada tecnologia da colonialidade do poder que

tem um lado visível / claro e um lado oculto / escuro. O lado visível / claro constrói hegemonicamente o gênero e as relações de gênero. Ele apenas organiza, de fato e de direito, a vida de homens e mulheres brancos e burgueses, mas constitui o próprio significado mesmo de "homem" e "mulher" no sentido moderno / colonial. (LUGONES, 2008: p. 98$)^{24}$

Os elementos selecionados e combinados pela ficção noticiam a modernização eurocentrada da cidade por meio do compartilhamento, entre produtores e leitores (textuais e imagéticos) dos imaginários sociais do progresso, da civilização e do branqueamento a partir dos quais a mulher gentrificada - o lado claro/visível do sistema colonial de gênero - é símbolo da civilização imoral da belle époque carioca.

Os atos que compõem esse jogo ficcional materializam o que nomeio de feminino gentrificado. Para sua composição recorro à noção de gentrificação. Segundo Maria Alba Sargatal Bataller, a gentrificação "consiste em uma série de melhorias físicas ou materiais e mudanças imateriais - econômicas, sociais e culturais - que ocorrem em alguns centros urbanos antigos, os quais experimentam uma apreciável elevação de seu status" (BATALLER, 2012: 10). A gentrificação também se caracteriza por uma transformação no perfil social dos centros gentrificados, isto é, com a valorização socioeconômica do espaço, as camadas economicamente abastadas deslocam as camadas populares que ali moravam. A gentrificação é, assim, uma “expressão espacial de uma profunda mudança social" (BATALLER, 2012: 10). A interação entre o cenário internacional e as especificidades da cidade analisada compõe os acontecimentos recíprocos e interatuantes da gentrificação. Nessa história, vemos o engendramento de novos estilos de vida amparados no desejo de distinção sociocultural e econômica dos gentrificadores.

Queremos sugerir que espaço e gênero se instituem instituindo um ao outro simultaneamente. A ficção pornô-erótica, num primeiro momento, desloca a tradicional separação do espaço - o público de domínio masculino e o privado de domínio feminino - ao associar mulher e urbanização. No entanto, esse deslocamento é apenas para ratificar tal separação, pois esse feminino gentrificado só se potencializa por uma imaginação masculina que, assustada com os novos comportamentos femininos, reafirma a 
superioridade de seu gênero ao silenciar ou debochar das ativistas mulheres que lutavam pela emancipação feminina, ambos validando a superioridade masculina:

\section{Comentários}

Toda a imprensa tem celebrado o movimento feminista nesta cidade, ultimamente. Ora é a A. M. B. [Associação da Mulher Brasileira], ora duas senhoras que foram eleitas para uma associação, ora outra representanteRevisão do sexo frágil que vai requerer o seu diploma de eleitora; um nunca acabar de agitação feminina. Está-se a ver que as saias estão se movimentando!

E quando as saias se movimentam é para subir!

As mulheres reclamam seus direitos e fazem muito bem. Há muito servicinho por aí que não fica bem aos homens, só feito por mulheres...

E depois... desde que o mundo é mundo, sempre foi mania das mulheres, meterem-se nas coisas dos homens... (Capirão Eutico. Rio Nu, 30. dez.1916)

O comentário do pseudônimo Capirão Eutico é um exemplo da demarcação de fronteiras entre masculino e feminino ativada pelas potências pornô-eróticas masculinas, especificamente direcionado às mulheres brancas. Brancas repita-se, pois mulheres não brancas, desde a colonização, sempre trabalharam, sempre foram forçadas a largar suas famílias, seus filhos para servirem como escravas e, mesmo após o fỉm da escravidão, continuaram (e continuam) sujeitas a diversas formas de exploração e violência. Por isso mesmo, suas existências foram estereotipadas pela imagem de controle da empregada doméstica, inferiorizando não só sua feminilidade, como sua própria humanidade. A suposta natureza feminina de fragilidade, recato e maternidade, inventada na modernidade ocidental ${ }^{25}$, não foi pensada para àquelas que têm o cotidiano marcado pelo trabalho pesado e inferiorizado no ordenamento social. Como as mulheres brancas, o sexo frágil, poderiam votar e trabalhar? Se as mulheres brancas exigiam direito ao trabalho, só poderiam fazê-lo por "servicinhos" que não eram dignos à masculinidade, ou seja, o texto hierarquiza atividades exercidas pelas mulheres (depreciadas) e as exercidas pelos homens (valorizadas). O movimento feminista é reduzido a uma movimentação de saias, a qual, num jornal pornô-erótico, só poderia ser para sua objetificação sexual: "E quando as saias se movimentam é para subir!. Ou: "desde que o mundo é mundo, sempre foi mania das mulheres, meterem-se nas coisas dos homens...". Novamente o duplo sentido: mulheres não devem "se meter" em política, reivindicar sua cidadania, ter acesso ao mercado de trabalho na profissão de sua escolha por serem "coisas de homens"; se meter em "coisas de homem" só se for para seu uso sexual - "desde que o mundo é mundo"... Em outros momentos dispensam o duplo sentido e vão direto ao ponto:

\footnotetext{
${ }^{25} C f:$ LAQUEUR, 2001.
} 
Pensamentos:

Nunca me humilharei a um homem, nunca me deixarei dominar por ele; mesmo quando chego à luta corporal com um desses entes desprezíveis, consigo sempre ficar por cima. Feminista (Rio $\mathrm{Nu}, 15.02 .1914)$

$\mathrm{O}$ ataque ao feminismo traduz a rejeição, e o medo, ao desafio de ter que reformular sua identidade, construída em oposição binária à feminina. A possibilidade de ter mulheres brancas exercendo as mesmas funções dos homens brancos é significada, na imaginação masculina daqueles que eram contra esse feminismo, como uma ameaça - o temor da comparação vexatória de estar exercendo a mesma função que uma mulher, a qual, apesar de compartilhar a mesma identidade étnico-racial, é de um gênero hierarquizado como antagônico e inferior. E se essa mulher fosse igual ou mais eficiente do que o homem - como poderiam continuar afirmando a sua superioridade? O conforto de ser o Senhor da rua e da casa é ameaçado pelo ativismo feminista. O medo era tamanho que Capirão Eutico afirma que toda a imprensa celebrava o feminismo na cidade do Rio de Janeiro. O que, tratando-se de uma imprensa majoritariamente masculina, na qual muitos dos próprios colaboradores do Rio $\mathrm{Nu}$ atuavam, não poderia estar mais longe da prática dessa discursividade ${ }^{26}$.

Se os gêneros também conformam estilos corporais de cada época, a genealogia política dos corpos pode problematizar os regulamentos normativos dos espaços públicos, pois as constantes citações das performances de gênero ${ }^{27}$ se naturalizam e se atualizam no espaço público da cidade. Daí a hierarquização dos corpos classificados como dignos de presença e atuação pública e os classificados como indignos de pertencimento ao mesmo. A chamada geografia de gênero "tem por objetivo principal a análise das relações entre espaço e gênero nas suas formas mais variadas, e nos papéis e funções que homens e mulheres ocupam nestas" (BORGHI, 2015: 134) ${ }^{28}$.

\footnotetext{
${ }^{26}$ A imprensa da Primeira República "se revelava implacável com a emancipação feminina". O discurso imagético ridicularizava os homens que faziam trabalhos domésticos enquanto suas mulheres saiam para trabalhar. Ironizavam a entrada da mulher branca no mercado de trabalho, na política, apresentando um mundo caótico pela inversão de papeis masculinos e femininos. Cf. MALUF \& MOTT, 1998.

27 Judith Butler argumenta que gênero é uma performance e não uma essência pré-estabelecida. $\mathrm{O}$ "verdadeiro sexo" (como ironiza Foucault) e o gênero podem ser entendidos como uma ficção social que, para funcionar, precisa ser repetida constantemente, de modo a garantir sua força reguladora dos papeis sociais femininos e masculinos. As constantes repetições das performances de gênero fundam e consolidam o sujeito. Embora exercida individualmente, tais ações são coletivas e temporais, objetivam a reprodução compulsória da heteronormatividade. Desse ponto de vista, os gêneros não são nem naturais, nem estáveis, são constituídos no tempo e no espaço. Cf. BUTLER: 2016).

${ }^{28}$ Segundo Rachele Borghi, essa modalidade da geografia começou na década de 1970, porém seu efetivo estabelecimento na disciplina geográfica se deu em 1984, com a publicação: An Introduction to feminist Geography pelo Women and Geography Group do Institute of British Geographers. Tal publicação, segundo Borghi, conferiu legitimidade científica à geografia feminista, estabelecendo "uma geografia que
} 
A mulher gentrificada possibilita uma função normatizadora do espaço e do convívio na capital do país. A representação de seu corpo e de seus hábitos produz e naturaliza uma europeização compulsória da imagem da cidade e de sua gente. O que não anula as possibilidades de deslocamentos e transgressões no dia a dia da urbe, pois "os corpos nunca obedecem totalmente às normas pelas quais sua materialização é fabricada." (ARAN \& PEIXOTO JR, 2007: 134). Por se tratar de uma representação pornô-erótica, esse feminino gentrificado tem a incumbência de difundir hábitos e práticas imoralmente civilizados, criando uma sensibilidade erótica moderna. $\mathrm{O}$ feminino gentrificado cria uma (obs)cena no interior da arena pornô-erótica: a dos corpos que não se enquadram no erotismo colonizado da belle époque carioca. Os corpos percebidos como socioeconomicamente pobres, negros, indígenas, asiáticos, nordestinos, obesos, entre outros, bem como os que ferem os gêneros binários, constituem sua (obs)cena, o lado escuro/invisível da colonialidade de gênero. Nesse ponto, podemos compreender as ambiguidades das potências pornô-eróticas masculinas. Ao mesmo tempo em que produzem a europeização da imagem da cidade e de sua gente, ao selecionar o imaginário pornô-erótico para dar vida e comunicabilidade ao seu projeto de modernidade, seus produtores ferem certa moralidade que posicionava o sexo como privado e para fins reprodutivos, regulado pelos ritos religiosos do casamento cristão e monogâmico, bem como recorreram a tais ficções para criticar o "atraso" da política da Primeira República.

leva explicitamente em conta o gênero criado socialmente no seio da estrutura da sociedade" (WGSG. Apud: BORGHI, 2015: 135). 


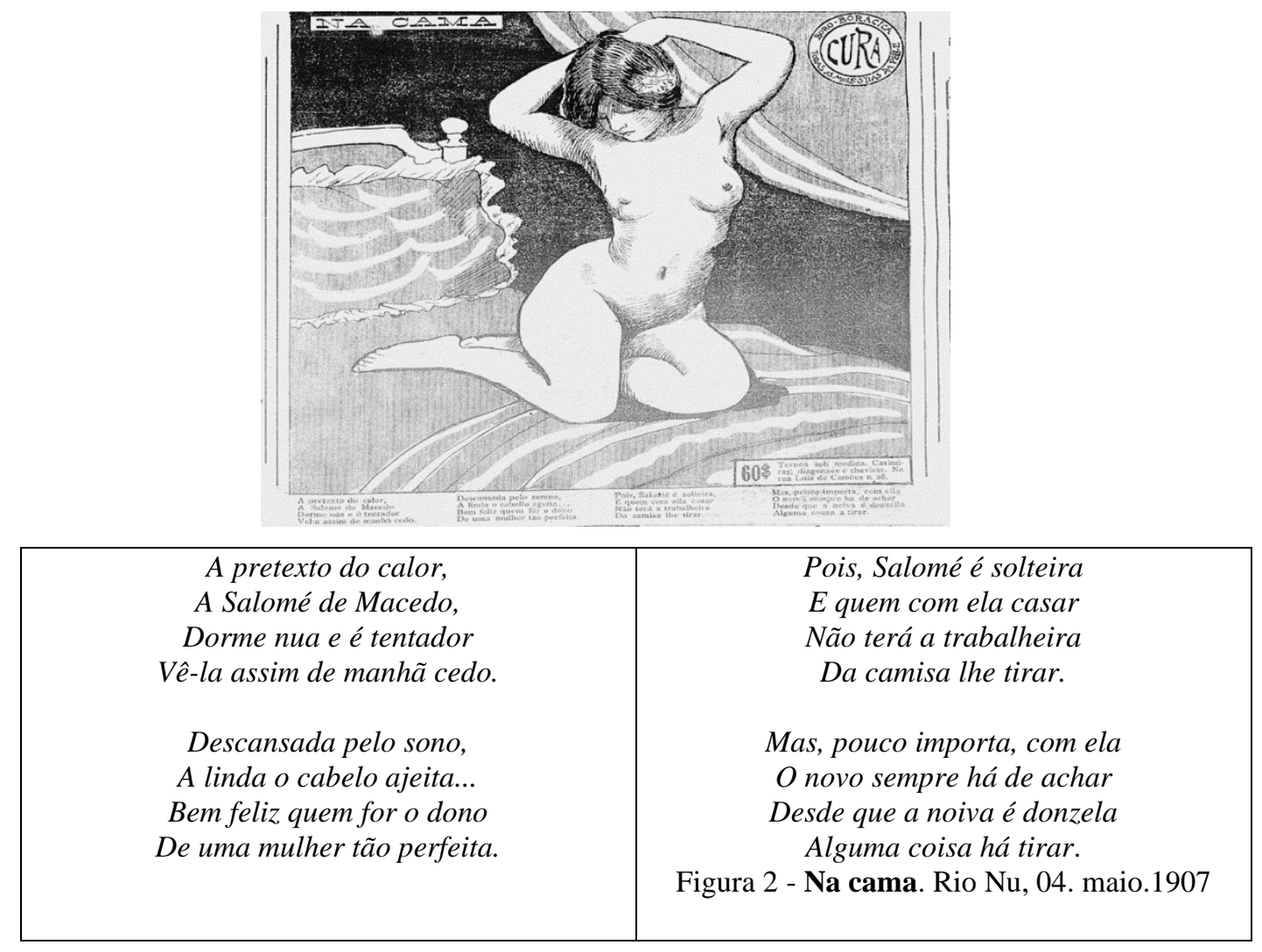

Mulher gentrificada: corpo branco, sensual, modelado pelas experimentações artísticas caras à tradição Ocidental: a mulher lânguida. O nome também dialoga com um tipo feminino do imaginário oitocentista: Salomé, a mulher fatal; ficção que orienta o leitor para a natureza de mulher em questão: o maldito feminino. O poder dessa Salomé vem de sua beleza tentadora, na qual será "bem feliz quem for o dono de uma mulher tão perfeita". Como recorrente nas potências pornô-eróticas masculinas, a mulher é um objeto de posse de seu Senhor, cuja perfeição pertence a seu "dono". Uma particularidade dessa escrita é o entrecruzamento entre o maldito e a pureza - para agradar a vaidade e orgulho virililista, essa Salomé é donzela - o catolicismo invade a imaginação erótica masculina.

Na coluna Cartas em Trânsito, na edição de 14 de fevereiro de 1914 do Rio Nu, o pseudônimo Indiscreto apresenta a história "De um moço elegante, que tinha a preocupação da linha. Contando a um amigo como se viu obrigado a quebrá-la". O nome dele era Petrônio, que se gabava por "conservar a linha da elegância, do bom tom, do chic, do belo, da estética, de tudo enfim que faz o verdadeiro homem da alta sociedade". Para manter a elegância só tinha relações sexuais com as mulheres "da alta roda". As prostitutas, mesmos as dos prostíbulos de alto luxo, não o interessavam, ele gostava era de ser amante das madames da alta sociedade, trocando-as constantemente para que elas não o julgassem “escravizado", o que, para ele, era também uma questão de "linha". Linha 
masculina em que jamais um homem pode se considerar preso a apenas uma mulher, o que demonstraria sua inferioridade, mesmo que tal "cativeiro" fosse à cama de uma dama da alta sociedade.

Com tal estratégia, Petrônio conseguiu conquistar a esposa de um rico comerciante. A Madame pediu para que ele fosse visitá-la diariamente, pois seu marido passava o dia fora e só voltava tarde da noite e, ainda, garantiu que não haveria problema porque "sua única criada - uma retinta crioula chamada Venância - era-lhe de uma fidelidade de cão", por isso vigiaria enquanto "enfeitavam com garlhadia a cabeça do negociante".

“Criada", "crioula retinta", “fiel como um cão” - essas são as orientações fictícias para o leitor formar suas representações sobre a mulher negra. As imagens de controle ${ }^{29}$ ativadas diminuem sua humanidade e aumentam sua animalização. A negra Venância é a materialização do esteriótipo da empregada doméstica, o qual tece uma linha associativa entre as mulheres negras da atualidade e a figura histórica da mãe preta dos tempos da escravidão ${ }^{30}$.

Assim passaram-se dias, onde tudo corria "sur de roulette, como diziam os franceses”. Até que um dia, Venância gritou para avisar que o patrão estava chegando e já tinha saltado do bonde. Rapidamente se vestiram, porém Petrônio não tinha por onde fugir. No desespero, ele teve uma ideia que não chamaria de "luminosa", nem que "o rachassem": ele resolveu fingir que era homem da Venância. Ao entrar em casa, o marido flagrou Petrônio a beijar "a cara retinta da fiel criada da Mme. X. Ao perguntar quem era aquele sujeito, Venância responde “- É o meu home, patrão...”. Então o negociante mandou Venância levá-lo para o quarto dela. E assim Petrônio passou algumas horas com Venância "a fazer mesmo de home de crioula..." E conclui: "Vê como o diabo as armas para obrigar um homem como eu a quebrar a linha?..."

A mulher negra, na ficção das Cartas em Trânsito, atua como polo opositor da mulher branca. A Madame - por ser branca, rica e elegante - é a mulher objeto do desejo das potências pornô-eróticas masculinas, dá vida ao feminino gentrificado. A criada - por ser negra, sobretudo negra, pobre e, por isso, ficcionalizada como inferior - atua como

\footnotetext{
29 'Fazer as mulheres negras trabalharem como se fossem animais ou 'mulas do mundo' é uma forma de objetificação. Negar a humanidade plena das mulheres negras, tratando-nos como o Outro objetificado em múltiplos binarismos, demonstra o poder que o pensamento binário, a diferença formada por oposições e a objetificação exercem nas opressões interseccionais (COLLINS, 2019: 138-139).

${ }^{30}$ Sobre os estereótipos que atravessam os corpos das mulheres negras brasileiras (a mulata, a mucama, a mãe preta, a empregada doméstica), $C f:$ : GONZALEZ, 1988.
} 
uma não-mulher: um fiel cão objeto não de desejo, mas da repulsa de uma masculinidade que se considera refinada, a qual afirma seu enjoo por ter estabelecido uma relação sexual com um ser indigno da linha, obrigado pelas "armas do diabo" a quebrar o seu decoro.

O caso do Rio $\mathrm{Nu}$ é de uma contradição rica em significados nessa questão. Há uma configuração negativa das afro-brasileiras, porém, em algumas edições, também há o louvor à beleza da mulata, bem antes da Era Vargas ou mesmo do movimento modernista. O que, por um lado, poderia ser para atender o mental set $^{31}$ de um público mais popular em comparação com outros jornais de gênero alegre (pornô-eróticos) do período voltados para setores da sociedade economicamente abastados; poderia ser também fruto da longa vida e grande quantidade de colaboradores do jornal - colunas nas quais pseudônimos como Pae Paulino e Capadócio assumem personalidades sociais populares; por outro lado, demonstra também as contradições e conflitos do desejo masculino:

\begin{tabular}{|c|c|c|}
\hline Modinhas Brasileiras & Que venha a branca falar & O que eu penso digo logo \\
Esta minha cor trigueira & Que eu meto-a no meu chinelo... & E sou bem franca em dizê-lo \\
Ninguém afirma que é má... & A mulata sabe amar & Nós somos quente igual fogo \\
É provocante e faceira & E apreciar o que é belo!... & E a branca é fria qual gelo! \\
Cor mais formosa não há! & Náo há mulher neste mundo \\
& Nano sabe nunca gozá-lo: & Como a mulata... ninguém!... \\
É cor que prende e arrebata & Conosco venha pra cá & Ninguém dá gozo mais fundo trabalha tão bem! \\
E não me causa isso pena: & Canta mais fino outro galo!... & (Rio Nu, Pae Paulino. 02. \\
Quando me chamam mulata & & ago.1899) \\
Respondo: eu cá sou morena! & & \\
\hline
\end{tabular}

A seleção operada nessa ficção privilegia a "mulata", significada como fatal: ela não tem "pena" se sua cor "prende e arrebata". Na combinação intratextual o leitor é orientado para representar sua cor não como inferior a branca, ao contrário: ele deve suspender o social-histórico corrente, que significava os afrodescendentes como portadores da degeneração da nação brasileira, para entrar no imaginário mobilizado por Pae Paulino. Pelo como se, a significação pré-determinada de sua cor é transgredida, "ninguém afirma que é má"; na orientação fictícia sua vaidade está presente em negar sua negritude: "Quando me chamam mulata/Respondo: eu cá sou morena!". Então, qual seria o poder da "mulata"? Ela põe a branca "fria qual gelo" "no chinelo", pois é "quente igual

\footnotetext{
31 Mental set para Gombrich: "Cada cultura e cada comunicação fundam-se no jogo recíproco de expectativa e observação, isto é, sobre os altos e baixos de satisfação e frustração, suposições corretas e movimentos errados que constituem a nossa vida cotidiana. A experiência da arte não se subtrai a essa regra geral. Um estilo, tanto quanto uma cultura ou uma mentalidade difundida, determina um certo horizonte de expectativa, uma postura mental (mental set) que registra todos os desvios e modificações com sensibilidade mais aguda". In: GOMBRICH, 1995: 46.
} 
fogo". Mesmo construindo a canção como se fosse a própria mulata, utilizando a narração em $1^{\text {a }}$ pessoa, se trata de sua objetificação, pois é o desejo masculino sobre as afrodescendentes que conduz a significação da escrita. Nessa ficção ela se torna desejada por proporcionar ao homem o "gozo mais profundo", pois, ninguém "trabalha tão bem" quanto a mulata.

Aqui a seleção operada pela ficção reconfigura literariamente a historicidade das relações sexuais entre brancos e negras correntes durante toda a escravidão. Muitos dos senhorzinhos tinham sua iniciação sexual com as escravas, bem como os Senhores (adultos e idosos) mantinham relações com as afrodescendentes, em sua maioria, relações ilegítimas e, muitas vezes, também forçadas e violentadas. Thiago Barcelo Soliva, ao analisar o pensamento de Gilberto Freyre, destaca a relação entre prostituição e escravidão:

a prostituição das "negrinhas" teria sido uma forma inaugural de comercialização dos corpos no Brasil Colonial. Esse comércio dos desejos era facilitado, em algumas situações, por suas donas brancas, verdadeiras proxenetas, que afiançavam suas escravas aos marinheiros nos portos coloniais. O rígido controle em relação à sexualidade das moças brancas contrastava com a lubricidade das mulheres negras, que deveriam sempre estar disponíveis à fornicação [...] Essa necessidade de evitar as mulheres brancas dos contatos com os homens alimentou-se da prostituição. Ademais, toda a vida pública da mulher branca era negada em função do enclausuramento nas 'Casas Grandes'. Essas eram fortemente submetidas aos olhares dos mais velhos, em um esforço premente de preservação da castidade. (SOLIVA, 2012: 318)

Daí a canção do Rio $\mathrm{Nu}$ conduzir o leitor ao avesso do imaginário pornô-erótico que elege a branca como desejável. A regulação da sexualidade das mulheres brancas é transformada em sua frieza, bem como mobiliza o imaginário da libido desenfreada da "mulata". Eis a tradição brasileira que classifica as mulheres como "a branca para casar, a negra para trabalhar e a mulata para o sexo", apenas. Segundo Sônia Maria Giacomini, a "mulata" é a saída brasileira de sua relação com a África, pois ela é a contraposição da africana, na qual a "mulata" se transforma em um produto positivo da miscigenação específica da sociedade brasileira. Na modinha de Pae Paulino, ela atua como elo entre o homem branco e a mulher negra/mulata articulados em uma festa pornô-erótica masculina, pois ela é "feita" para os "gozos mais profundos", “isentando-a" dos tradicionais papeis de gênero feminino. Dessa forma, "a transformação de mulher negra em mulata irresistível - do ponto de vista do homem branco - reconstrói a relação de dominação, racial e sexual, enquanto resultado de atributos naturais da própria mulher negra/mulata" (GIACOMINI, 1994: 223). Situada nas potências pornô-eróticas 
masculinas que elegem a mulher branca moderna como a desejante, sua rara presença nos jornais de gênero alegre como mulher sedutora e voluptuosa, instaura mais um dilema para a masculinidade na arena pornô-erótica: que mulher devo desejar?

A mulher negra, classificada na imagem de controle da "mulata" "provocante" e "faceira", institui instituindo a negra como objeto sexual do macho/branco, a qual vive para seduzi-lo por sua volúpia "desenfreada". Aqui as relações de dominação raciais, perigosas e violentas, são esvaziadas e naturalizadas pela transformação da "mulata" em símbolo da sexualidade da mulher brasileira ${ }^{32}$. A estereotipização é, dessa forma, um dispositivo de poder que inferioriza subjetividades, simplifica alteridades e normatiza existências desordenadoras da colonialidade de gênero. Daí a importância de racializar as análises das relações de gênero para a desnaturalização das opressões de raça, gênero e classe.

Feminino gentrificado: signo e símbolo da belle époque imoral. As repetições das performances de gênero masculina e feminina, articuladas com o imaginário da civilização orientado pela ficção pornô-erótica, institui instituindo um erotismo moderno/colonial. Noção que leva em consideração categorias como cor, classe, sexualidade e regionalidade, as quais são selecionadas e combinadas para produção dessa ficção. A mulher gentrificada tem uma determinada cor (branca), classe (média alta e burguesa), sexualidade (heterossexual e, às vezes, bissexual para o voyeurismo masculino) e regionalidade (carioca urbana à luz da francesa). As ficções pornô-eróticas masculinas, que faziam sucesso pelo tema e por trabalharem com o horizonte de expectativas de grande parte de seu público, institui instituindo um social-histórico no qual se nega a desigualdade social, a herança colonial e escravista; possibilitando a imaginação de outro feminino - gentrificado, repita-se -, o qual é celebrado como marca da modernidade carioca. Assim almejavam difundir a imagem de uma cidade branca, socioeconomicamente abastada e imoralmente civilizada, configurando a colonização do desejo dessa masculinidade.

\footnotetext{
32 “A conversão de símbolos étnicos em símbolos nacionais não apenas oculta uma situação de dominação racial mas torna muito mais difícil a tarefa de denunciá-la, Quando se convertem símbolos de "fronteiras" étnicas em símbolos que afirmam os limites da nacionalidade, converte-se o que era originalmente perigoso em algo 'limpo', 'seguro' e domesticado" (FRY, 1982: 47).
} 


\section{Potências pornô-eróticas femininas: o feminino vivificante}

Eu sinto que nasci para o pecado, se é pecado, na Terra, amar o Amor; anseios me atravessam, lado a lado, numa ternura que não posso expor. Filha de um louco amor desventurado, trago nas veias lírico fervor, $e$, se meus dias a abstinência hei dado, amei como ninguém pode supor. Fiz do silêncio meu constante brado, e aо que quero costumo sempre opor o que devo, no rumo que hei traçado. Será maior meu gozo ou minha dor, ante a alegria de não ter pecado e a mágoa da renúncia deste amor?

(Gilka Machado)

A pornografia abala o ordenamento social que se diz limpo, puro, polido, perfeito. No entanto, uma presença perturba a tradição pornô-erótica, ela se chama mulher. Sombra das luzes desse imaginário, ela é situada como objeto do desejo masculino que, no entanto, não permite sua existência como sujeito de seu próprio prazer. Por isso, sua condição contraditória: terrível prazer em que o homem a deseja, mas teme sua natureza misteriosa, maldita. Ela "nasce para o pecado": Dalilas, Judiths, Helenas, Salomés, Evas, Gilkas - pecadoras por ser “pecado, na Terra, amar o Amor". E se essa mulher, além de ter escolhido a ficção pornô-erótica, fosse também afrodescendente e socioeconomicamente vulnerável... Em uma sociedade marcada pelo sistema colonial de gênero, ela é o real terror ${ }^{33}$ que se apresenta a uma masculinidade colonizada e amedrontada por suas potências. Essa mulher não se conforma. Anseios a atravessam, lado a lado, dividida entre o dever e o querer. Será maior o bem das dores de se manter calada ou o gozo do grito libertador? Apresento àquela que escolheu as delícias do mal libertador - a poesia de Gilka Machado ${ }^{34}$.

Outra Salomé invade a discursividade pornô-erótica. Tema caro ao decadentismo ${ }^{35}$ do período, arquétipo de mulher fatal que, em Gilka, ganha contornos e significações inéditas.

\footnotetext{
${ }^{33}$ Noël Carroll diferencia entre "horror" e "terror", os quais são gêneros que: "embora lúgubres e atemorizantes, conseguem seus efeitos apavorantes explorando fenômenos psicológicos, todos eles demasiados humanos. Correlacionar o horror com a presença de monstros dá-nos uma boa maneira de distingui-lo do terror, sobretudo do terror enraizado em histórias de psicologias anormais" (CARROLL, 1999:31).

${ }^{34}$ Sobre a vida de Gilka Machado e suas repercussões na impressa da época, $C f .:$ CARVALHO, 2018: 138180.

${ }^{35}$ Decadentismo: "expressão lançada contra a nova arte, em França, e que Moréas teve a altivez de aceitar, como um desafio" (MURICY, 1973: 36).
} 


\begin{tabular}{|c|c|c|}
\hline $\begin{array}{c}\text { Dançarás por amor das coisas e } \\
\text { dos seres. } \\
\text { e por amor do Amor... } \\
\text { tua dança dirá renúncias e } \\
\text { quereres! } \\
\text { Faze com que desfira } \\
\text { Tua lira } \\
\text { ge dor, } \\
\text { gargalhadas de gozo e lamentos } \\
\text { e possas em teu ritmo recompor } \\
\text { tudo que visite estática } \\
\text { surpresa, } \\
\text { e a imprevista beleza, } \\
\text { a beleza incorpórea } \\
\text { dos perfumes e sons indefinidos } \\
\text { de tudo que te andou pelos } \\
\text { sentidos, } \\
\text { de tudo que conservas na } \\
\text { memória. }\end{array}$ & 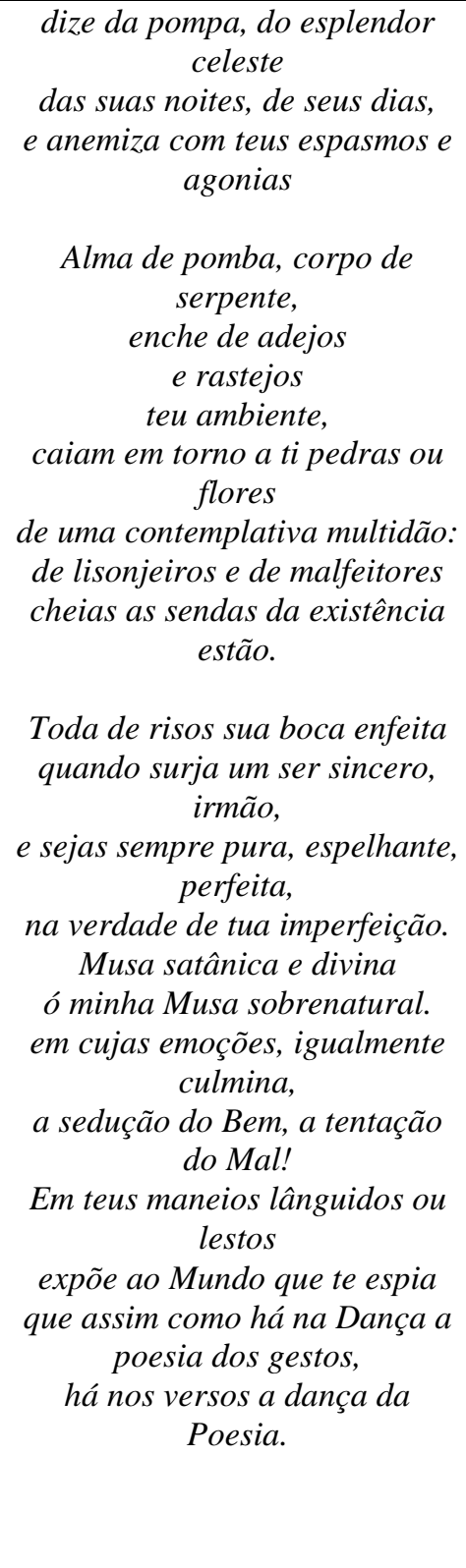 & 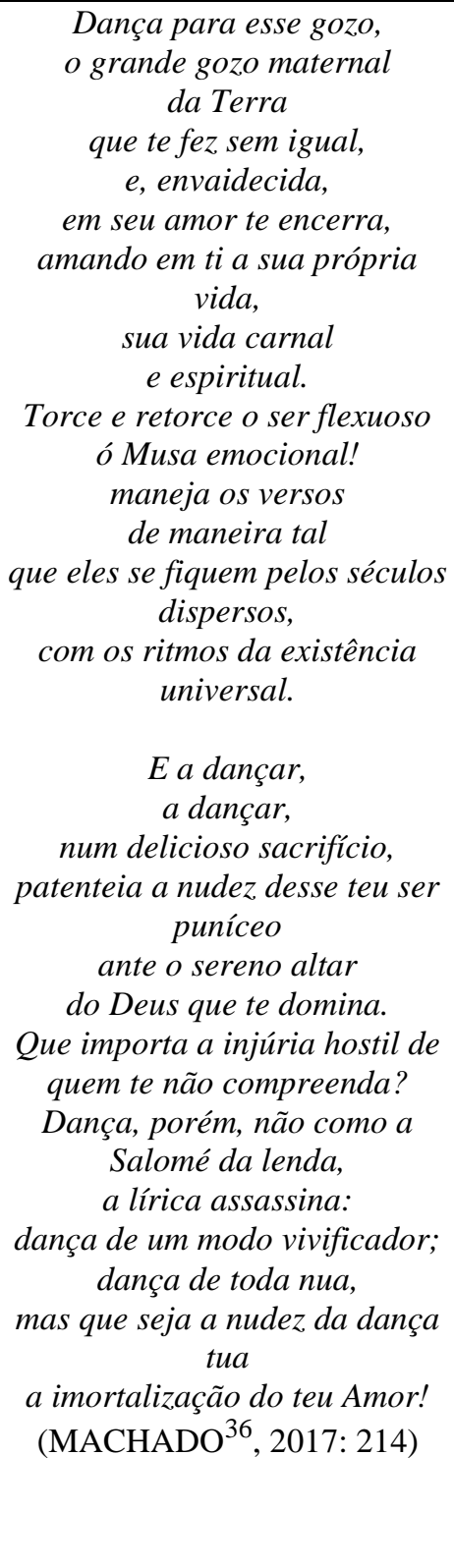 \\
\hline
\end{tabular}

“Assim, assistimos a exaltação de um Eros vivificante que impera na emoção da poeta e em todas as manifestações da Natureza" (FERREIRA, 2002: 93). A Salomé de Gilka Machado dança não por sua natureza maldita, mas "por amor das coisas e dos seres e por amor do Amor." A edificação de um novo feminino não é construída em um solo perfeito e harmonioso por exigir "renúncias e quereres" - renúncia a sua natureza maldita, à dominação patriarcal; quereres de transformação do como ser mulher. Dança cuja transgressão aos papeis de gênero instituídos provocam "gargalhadas de gozo e lamentos de dor". Pela ousadia de exibir sua dança - em uma sociedade na qual a manutenção do

\footnotetext{
${ }^{36}$ Poema publicado originalmente no $3^{\circ}$ livro de poemas de Gilka Machado: Mulher Nua, em 1922.
} 
aprisionamento feminino e a luta por sua emancipação estavam em confronto - cairão sobre ela "pedras ou flores de uma contemplativa multidão". A dança de Salomé é de uma explosão erótica angustiante, pois seus gestos unem o desejo de libertação e o aprisionamento social. Por isso sua dança harmoniza, em seu eu lírico, a "verdade de sua imperfeição". Ela é "musa satânica e divina" que na vida entrecruza "a sedução do Bem, a tentação do Mal", pois o mundo que a "espia" ela põe em xeque o homem, macho, ocidental. Ela dança num terrível- prazer de um "gozo maternal": ao oferecer um "delicioso sacrifício" - "a Salomé da lenda, a lírica assassina" - a Terra fez nascer "sem igual" um novo feminino: não o maldito e sim o vivificador, cuja nudez imortaliza o seu amor. Eis o feminino vivificante de Gilka Machado, parida no sacrifício da maldita, o avesso do feminino gentrificado, senhora e soberana de suas dores e delícias ${ }^{37}$.

O corpo da mulher é um grande palco de conflitos e disputas da arena pornôerótica do Rio de Janeiro nas primeiras décadas do século XX. Nessa estratégia de normatização colonizada da mulher do desejo, encontro uma tática para sua possível libertação, um desejo de ser livre em: Aspiração, de Gilka Machado

\begin{tabular}{|c|c|c|}
\hline $\begin{array}{c}\text { Aspiração } \\
\text { Eu quisera viver sem leis e sem } \\
\text { senhor, } \\
\text { tão somente sujeita às leis da } \\
\text { natureza, } \\
\text { tão somente sujeita aos } \\
\text { caprichos do amor... } \\
\text { viver na selva acesa } \\
\text { pelo fulgor solar, } \\
\text { o convivio feliz das mais aves } \\
\text { gozando, } \\
\text { viver em bando, } \\
\text { a voar, a voar. } \\
\text { Eu quisera viver cantando como } \\
\text { as aves } \\
\text { em vez de fazer versos, }\end{array}$ & $\begin{array}{c}\text { Eu quisera viver dentro da } \\
\text { natureza, } \\
\text { sufoca-me a estreiteza } \\
\text { desta vida social a que me sinto } \\
\text { presa. } \\
\text { Diante } \\
\text { de uma paisagem verdejante, } \\
\text { diante do céu, diante do mar, } \\
\text { esta minha tristeza } \\
\text { por momentos se finda } \\
\text { e desejo sofrer a vida ainda } \\
\text { e fico a meditar: } \\
\text { como os homens são maus e } \\
\text { como a terra é linda! }\end{array}$ & $\begin{array}{c}\text { Eu quisera viver a voar, a voar } \\
\text { até sentir as asas molentadas, } \\
\text { voar ao cair do sol e ao vir das } \\
\text { alvoradas, } \\
\text { voar mais, ainda mais, } \\
\text { pairar bem longe das criaturas } \\
\text { nas sereníssimas alturas } \\
\text { celestiais. } \\
\text { Voar mais, ainda mais } \\
\text { (o vôo me seduz) } \\
\text { voar até, finalmente, } \\
\text { num dia muito azul e muito } \\
\text { ardente, } \\
\text {-alma - pairar do espaço à } \\
\text { flux, }\end{array}$ \\
\hline
\end{tabular}

\footnotetext{
${ }^{37} \mathrm{O}$ termo feminino vivificante é uma noção teórico-metodológica elaborada por esse estudo com base na poesia de Gilka Machado, sendo o termo "vivificante" empregado pela poetisa em: Comigo Mesma; dialoga também com a dissertação de mestrado em literatura de Marcela Ferreira, na qual a autora analisa as transformações no decadentismo por meio da poesia de Gilka, de seu "Eros Vivificante": "Como ameniza o satanismo da musa, Gilka opera mudanças nos arquétipos literários fixados pelo decadentismo, de modo que sua poesia entra em conflito com as convenções literárias perfazendo um movimento de alianças e embates com a tradição" (FERREIRA, 2002: 9). O feminino vivificamte se contrapõe a outra noção elaborada por esse estudo: o feminino gentrificado. (CF.: CARVALHO, 2018). Para elaboração teóricometodológica desses tipos de femininos foram fundamentais o diálogo com o imaginário social de Cornélius Castoriadis (1982); a relação entre imaginário, realidade e ficção de Iser Wolfgang (2013), bem como noções teórico-metodológicas específicas dos estudos de gênero: o caráter agonístico da política de Chantal Moufe (2015); as noções de performances de gênero de Judith Butler (2016); as imagens de controle a intersecionalidade do pensamento feminista negro (COLINS, 2019; CRENSHAW, 2002;) e a colonialidade de gênero de Maria Lugones (2008; 2014).
} 


\begin{tabular}{|c|c|c|}
\hline $\begin{array}{c}\text { sem poderem assim os humanos } \\
\text { perversos }\end{array}$ & $\begin{array}{c}\text { se, das aves seguindo o exemplo } \\
\text { encantador, }\end{array}$ & $\begin{array}{c}\text { Fio'matéria - despenhar-me de } \\
\text { interpretar perfidamente } \\
\text { meu cantar. }\end{array}$ \\
$\begin{array}{c}\text { a humanidade livremente unida, } \\
\text { gozasse a natureza, a liberdade } \\
\text { e o amor. [...] }\end{array}$ & $\begin{array}{c}\text { sobre a terra absorvente, } \\
\text { morta, morta de luz! } \\
(\mathrm{MACHADO}, 2017: 138)^{38}\end{array}$ \\
\hline
\end{tabular}

O eu lírico instaura um confronto entre a civilização - onde humanos perversos a aprisionam - e a natureza - a possibilidade do voo transcendente/libertador. Quantas mulheres sonharam (e sonham) com uma existência sem leis, as quais retiram os seus direitos sobre si e seu corpo; e sem senhores de suas vidas a dominá-las e inferiorizá-las. O feminismo em Gilka, diferente do Ser Mulher, de Cristais Partidos, vai se tornando menos apologético e mais poético, como nessa poesia do livro Estados de Alma. Aqui a poetisa seleciona problemas existentes em seu tempo, combinados por um imaginário de libertação feminina, articulados pela orientação ficcional, na qual se pode atingir a significação da dor revolucionária do eu lírico. A condição feminina na sociedade patriarcal é uma fonte de dores coletivas poetizadas por Gilka Machado. Em contraposição à “estreiteza desta vida social” que a aprisiona, Gilka apresenta o sonho do voo etéreo em que a natureza supera tal civilização, em que a superação do emudecimento feminino instituído pelo patriarcalismo, transforma-se em um dizível: o voo.

A libertação do corpo da mulher, da objetificação à condição de sujeito de seu próprio prazer, é um dos confrontos que a escrita feminina instaura na arena pornôerótica. Uma potência liberada pela escrita da Dionísica ${ }^{39}$ - um terrível-prazer de mulher se apresenta em mais um poema de seu livro: Estados de Alma (1917):

\begin{tabular}{|c|c|c|}
\hline $\begin{array}{c}\text { Muitas vezes, a sós, eu me } \\
\text { analiso e estudo, } \\
\text { os meus gostos crimino e busco, } \\
\text { em vão torcê-los; } \\
\text { é incrível a paixão que me } \\
\text { absorve por tudo } \\
\text { quanto é sedoso, suave ao tato: } \\
\text { a coma... Os pelos... } \\
\text { Amo as noites de luar porque } \\
\text { são de veludo, } \\
\text { delicio-me quando, acaso, sinto, } \\
\text { pelos } \\
\text { meus frágeis membros, sobre o } \\
\text { meu corpo desnudo } \\
\text { em carícias sutis, rolarem-me os } \\
\text { cabelos. }\end{array}$ & $\begin{array}{c}\text { O meu tato se estende a todos } \\
\text { os sentidos; } \\
\text { sou toda languidez, sonolência, } \\
\text { preguiça, } \\
\text { se me quedo a fitar tapetes } \\
\text { estendidos. } \\
\text { Tudo quanto é macio os meus } \\
\text { ímpetos doma, } \\
\text { e flexuosa me torna e me torna } \\
\text { felina. } \\
\text { Amo do pessegueiro a } \\
\text { pubescente poma, } \\
\text { porque afagos de velo oferece e } \\
\text { propina. } \\
\text { O intrínseco sabor lhe ignoro; } \\
\text { se ela assoma, }\end{array}$ & $\begin{array}{c}\text { Toco-a, palpo-a, acarinho o seu } \\
\text { carnal contorno, } \\
\text { saboreio-a num beijo, evitando } \\
\text { um ressabio, } \\
\text { como num lento olhar te osculo } \\
\text { o lábio morno. } \\
\text { Toco-a, palpo-a, acarinho o seu } \\
\text { carnal contorno, } \\
\text { saboreio-a num beijo, evitando } \\
\text { um ressabio, } \\
\text { somo num lento olhar te osculo } \\
\text { o lábio morno. } \\
\text { E que prazer o meu! que prazer } \\
\text { insensato! } \\
\text { - pela vista comer-te o pêssego } \\
\text { do lábio, }\end{array}$ \\
\hline
\end{tabular}

\footnotetext{
${ }^{38}$ Publicado originalmente em seu $2^{\circ}$ livro - Estados de Alma (1917).

${ }^{39}$ Dionísica era como grande parte da imprensa da época chamava Gilka Machado. Cf.: CARVALHO, 2018.
} 


\begin{tabular}{|c|c|c|}
\hline $\begin{array}{c}\text { Pela estação, que aos mais seres } \\
\text { eriça, }\end{array}$ & $\begin{array}{c}\text { no rubor da sazão, sonho-a } \\
\text { doce divina! }\end{array}$ & $\begin{array}{c}\text { e o pêssego comer apenas pelo } \\
\text { tato. }\end{array}$ \\
$\begin{array}{c}\text { andam-me pelo corpo espasmos } \\
\text { repetidos, }\end{array}$ & $\begin{array}{c}\text { gozo-a pela maciez cariciante, } \\
\text { de coma, }\end{array}$ & (MACHADO, 2017: 172) \\
às luvas de camurça, às boas, à & e o meu senso em mantê-la \\
pelica... & incólume se obstina... & \\
\hline
\end{tabular}

O novo, o explosivo, a revolução da poesia de Gilka Machado, ocorre no corpo da mulher. Outra possibilidade de "ser mulher" se potencializa: experimentando e analisando seu corpo, suas sensações - "meus frágeis membros, sobre o meu corpo desnudo em carícias sutis". Sozinha em seus pensamentos e desejos, seu tato "se estende a todos os sentidos"; e é tomada pela languidez "do pessegueiro a pubescente poma": ela toca, apalpa "seu carnal contorno" e goza o "prazer insensato" de comer o "pêssego do lábio e o pêssego comer apenas pelo tato". Sua transgressão aos regramentos sociais se realiza pelo deslocamento das tradicionais performances de gênero feminino: é a valorização do corpo e do desejo da mulher que se apresenta na arena pornô-erótica. Seu corpo exposto, sem ser mero objeto sexual, é arrebatado por ser sensível a tudo que está em sua volta - um homem, um sândalo, um pêssego... Seu corpo é um todo de sensações que explode pelo terrível-prazer do toque em si mesma em que aflora seu desmantelamento erótico.

Até aqui, poderíamos concluir que a criação pornô-erótica do início das primeiras décadas do século XX, para além dos embates de gênero travados pelo aparecimento das potências pornô-eróticas femininas, não apresentaria uma inflexão étnico-racial ou de classe. No entanto, originalidade transgressora da escrita de Gilka Machado se entrecruza a singularidade étnico-racial e socioeconômica de sua presença no meio literário de então. Entre as escritoras que publicaram ficções pornô-eróticas no período, Machado é a única que, além de mulher, era afrodescendente e socioeconômica desprivilegiada. Os ataques a sua vulnerabilidade socioeconômica, bem como a cor da sua pele, foram constantes em sua carreira ${ }^{40}$. Essa singularidade se desdobra em sua

\footnotetext{
${ }^{40}$ Um exemplo de tais ataques, está em uma carta escrita pelo médico, político, professor, crítico literário, romancista e imortal da Academia Brasileira de Letras, Júlio Afrânio Peixoto, enviada ao também imortal da ABL, Humberto Campos, sobre seu encontro com Gilka Machado: "Você não imagina a tristeza que senti outro dia. Recebi de Gilka Machado o pedido de uma parte da minha obra, ou de um fragmento inédito, para uma antologia que ela estava reunindo. E me deram o seu endereço. Como era perto daqui, da Câmara, na rua da Misericórdia, e eu tinha a resposta no meu bolso, decidi ir entregá-la pessoalmente, ou seja, à doméstica ou a quem me recebesse. Subi uma pequena escada suja e sombria e me adentrei no segundo andar, diante de uma porta que fecha um corredor escuro. Bati e me apareceu uma pequena mestiça sombria, em chinelos, com um vestido caseiro. Perguntei se era lá que vivia a Senhora Gilka Machado. / - Sim, senhor; sou eu mesma - me respondeu a pequena mulata. Faça gentileza de entrar, doutor.../Eu não entrei. Entreguei a carta me desculpando e parti... Mas, seu Humberto, que tristeza! Eu não conhecia Gilka, a não ser por retrato: jovem mulher branca, atraente, chamando atenção... E eu tive pena de a ver nesse pardieiro,
} 
escrita. A imaginação, logo a possibilidade de um novo tipo de feminino se apresenta nessa arena pornô-erótica, o qual se constrói, justamente, nas fronteiras do feminino gentrificado. Se a mulher gentrificada se realiza pela sombra das mulheres socioeconomicamente vulneráveis, a poesia de Gilka é o seu avesso. Ela não silencia as mulheres das camadas populares, ao contrário:

\begin{tabular}{|c|c|}
\hline A uma lavadeira & Não poderei, por mais que queira, \\
Minha vizinha lavadeira, & dado me fosse e dos desvãos \\
mal nasce o sol, põe-se a cantar, & da minha dor tirara inteira \\
canta a manhã, a tarde inteira, & esta alma, ó linda lavadeira, \\
mais me parece uma rendeira & para o crisol de tuas mãos. \\
nivosos sons desfiando no ar. & \\
De suas mãos o alvor é tanto & Ao teu labor, que assim perdura, \\
que, às vezes, tenho a convicção & tenho este anseio singular: \\
de que, talvez por um encanto & pudesses tu, leda criatura, \\
alvo se torne tudo quanto & lavar minha alma da amargura \\
os dedos seus tocando vão. [...] & e pô-la ao sol para secar. \\
& (MACHADO, 2017: 244) \\
\hline
\end{tabular}

Na poesia: A uma lavadeira, há o entrecruzamento entre a sensibilidade e o trabalho, no qual o canto da lavadeira encanta o ar. Suas mãos de trabalhadora não são impuras, ao contrário, tudo se torna alvo com o toque dos seus dedos. Versos que dignificam o trabalho da linda lavadeira, cujas mãos, se ela pudesse, daria sua alma a lavar. Na seleção dos pontos referenciais, Machado escolhe um tipo de mulher das camadas populares como motivo de sua lírica, tornando presente na cena literária brasileira estas mulheres silenciadas e inferiorizadas pelo ordenamento social. Em Mulher Nua, a poetisa escolhe alguns temas populares, como a gente simples do campo e da cidade (como a lavadeira), o que, segundo Gilberto de Araújo ${ }^{42}$, não significa sua adesão aos preceitos modernistas e sim o poetizar de sua herança familiar ${ }^{43}$. Nada mais longe do feminino gentrificado. Aqui é a mulher real, do dia a dia, que passa pela rua com saco de roupa na cabeça; trabalhadoras informais tão presentes e atuantes nas ruas do Rio de Janeiro:

onde tudo respirava à pobreza e quase à miséria" (PEIXOTO, apud: DAL FARRA, 2017: 47-48. Grifos meus).

${ }^{41}$ Poema publicado originalmente em seu livro: Mulher Nua, de 1922.

${ }^{42}$ Cf.: ARAÚJO, 2017.

${ }^{43}$ Nascida no bairro do Estácio, a arte esteve presente na vida da poetisa desde sua infância. Seu pai, Hortêncio da Gama Souza Melo, "culto, bonito, inteligente e boêmio"; sua mãe, Teresa Costa, a quem dedica seu primeiro livro, "foi uma heroína, bonita e inteligente, enfrentando todas as dificuldades da vida sem desânimo, conseguindo obter um nome de relevo no teatro e no rádio" (MACHADO, 2017: 14); seu avô materno, Francisco Pereira da Costa era violinista; seu bisavô, Francisco Moniz Barreto, foi um famoso repentista baiano. 


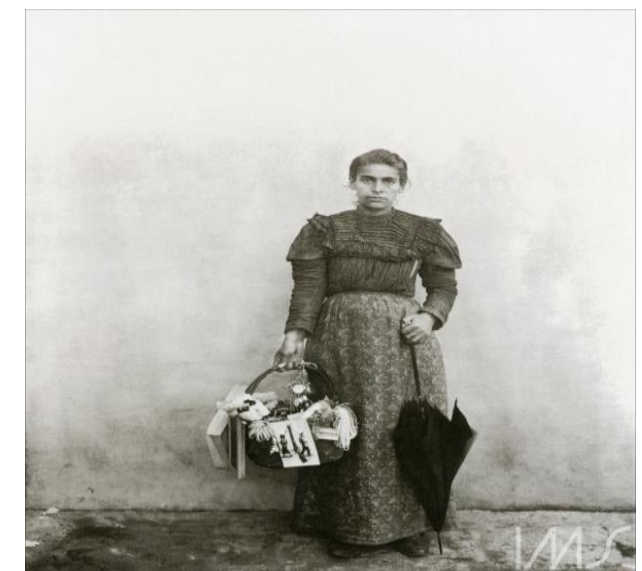

Figura 1 - Vendedora de miudezas. FERREZ, 1895.

A vendedora de miudezas, assim como a lavadeira de Gilka Machado:

\begin{abstract}
transitavam pelas ruas num "sem-lugar" de trabalho, mas que, por isso mesmo, poderiam atuar em diversos lugares: presença constante e volátil no espaço público carioca. Para elas a rua não era apenas local de passagem - função dada pela modernidade -, mas um espaço de vivência: trocas simbólicas, redes de sociabilidades, local de trabalho, etc. (CARVALHO, 2012: 93)
\end{abstract}

Muitas vezes essas trabalhadoras eram enquadradas no Artigo 399 do Código Penal Republicano (BRASIL, 1890), o qual determinava a contravenção da vadiagem para aquelas e aqueles que não tivessem como comprovar sua renda ou que exercessem um trabalho informal ou que não tivessem um domicílio certo (cortiços e casas de cômodos não eram considerados). Ou seja, a contravenção da vadiagem era uma das formas de criminalização da pobreza, principalmente, se ela estivesse presente no Centro ou na Zona Sul do Rio de Janeiro - regiões destinadas ao desfrute da classe média alta e burguesa da sociedade carioca. No entanto, para as mulheres das camadas populares, serem presas como vadias "associava-se a questões morais - a forma adequada de se apresentar e de agir na urbe, ficando a moradia e o trabalho em segundo plano" (CARVALHO, 2012: 159). A prisão da mulher como vadia era uma punição pela transgressão às performances de gênero feminino. Na poesia de Gilka Machado, que conhecia o cotidiano dessas mulheres por sua vulnerabilidade socioeconômica (criada no subúrbio do Rio de Janeiro), elas não são nem vadias, nem desprezíveis como nas potências pornô-eróticas masculinas; são pontos referencias da sociedade que figuram como musas de sua lírica em diálogo com o imaginário de emancipação feminina pelo trabalho, orientado em sua ficção pela beleza sensível de suas atividades. 
Se a mulher gentrificada é fundamentalmente branca e se realiza à sombra das negras; se o seu linguajar e comportamentos são afrancesados; na poesia de Gilka a mulher tem a diversidade das formas, falas e cores tropicais, como as negras da Bahia.

\begin{tabular}{|c|c|c|}
\hline Negra Baiana & Dos lábios polpudos & a negra baiana \\
Feira da água do Menino & dos dentes perfeitos & que é todo exotismo \\
(delícias expostas à beira do & que rosas de risos a & que encanta o turismo \\
mar) & desabrochar!... & e em sua ignorância lições sabe \\
e a noite indagando com fala de & ô negra baiana & dar. \\
afago: & de curvas & Ó negra baiana \\
"Iaiá que é que quer comprar? & tão turvas, & de estranha figura \\
Da bata bordada, de alvíssima & nos gestos macios, & que rezas ensinas \\
alvura. & na voz carinhosa & contra a desventura \\
emerge um pescoço de ônix, & és branco manjar. & que a todos prometes \\
reluzente & Bahia das artes & que ditas receitas \\
e os braços carnudos & Bahia da ciência, \\
e o colo opulento, & Bahia da vivência & de feitiçarias... \\
sugerem embalos, canções de & de fraternidade & tu fazes que eu veja este mundo \\
ninar. & ao progresso não permitas & com a alma melosa do doce do \\
& superar & sonho.
\end{tabular}

Aqui, a musa inspiradora não tem a linguagem afrancesada, mas sim o falar doce e malemolente da Bahia. Sua pele não é branca e sim de uma beleza negra como a de um “ônix”; seus lábios não são finos, são "polpudos” e com "dentes perfeitos” que se abrem em risos como "rosas a desabrochar". O corpo da negra baiana não é motivo de ojeriza, ao contrário: "braços carnudos, colo opulento, gestos macios, voz carinhosa"; corpo de uma beleza de "curvas turvas", saboroso como um "manjar". A modernização - as "artes, ciência e progresso" - não poderia superar o "exotismo" da negra baiana que "encanta o turismo" e "em sua ignorância lições sabe dar", assim a poetisa celebra sua alma de doce sonho em substituição ao mundo tristonho. O conhecimento da negra baiana, enquadrado pelas tecnologias da colonialidade do poder como "exótico", é poetizado por Machado. A modernidade/colonial que nega o solo brasillis, em Gilka, não elimina e nem supera os outros saberes das mulheres negras da Bahia. Uma outra mulher do desejo se potencializa nas poesias da Dionísica, a qual se confronta com a mulher do desejo das potências pornôeróticas masculinas.

Negra baiana - um eu lírico em contemplação erótica diante da beleza de um "pescoço de ônix" e de "lábios polpudos". Vida e obra se entrecruzam na escrita de Machado. Neste momento mais maduro de sua obra, com a experiência de muitos anos de embates com a sociedade por sua "ousadia" de se apresentar como uma mulher de

\footnotetext{
${ }^{44}$ Publicado originalmente em seu livro: Sublimação (1938).
} 
letras erótica, a poesia Negra Baiana rompe com o binarismo efetivado pelo sistema moderno/colonial é ressignificada por Gilka Machado. O lado oculto / invisível - os fenótipos das mulheres afrodescendentes e seus saberes - se tornam visíveis/ claros por essa poesia decolonial; seus versos potencializam uma sensibilidade erótica à sombra do desejo colonizado da Belle Époque Imoral. Ou seja, os trejeitos, o luxo e o ócio das madames afrancesadas da alta sociedade carioca, bem como as mulheres negras estereotipadas em imagens de controle, são o avesso da beleza e do encanto de uma trabalhadora negra das ruas da Bahia, que pergunta ao final do dia: "Iaiá que é que quer comprar?”. Gilka transforma em poesia o que posteriormente Lélia Gonzalez nomeia de pretoguês - a africanização da forma brasileira de falar o português ${ }^{45}$. A palavra iaiá é uma expressão de tratamento dado às moças durante a escravidão, derivada da alteração da palavra sinhá - "senhora" no falar dos escravos. Machado traz para a cena poética o pretoguês característico da Bahia, expresso também pelo sotaque tonal e rítmico do pretoguês baiano. Em sua poesia erótica, as transgressões de gênero se entrelaçam a transgressões de classe e de raça ao possibilitar no imaginário social da época outras representações para mulheres negras e pobres.

Na escrita de Gilka, o erótico não elimina o social, ao contrário, a poetisa instaura na cena literária mulheres silenciadas - lavadeiras, negras baianas, filhas de terreiro da sociedade brasileira; sedutoras pela beleza de sua existência. O que promoveu uma originalidade altamente transgressiva de um tema clássico do cânone artístico-literário Ocidental - a musificação ${ }^{46}$.

As musas inspiradoras de Machado não eram de natureza maldita, nem se restringiram aos padrões eurocentrados e aristocráticos. O tema atravessa não só a produção poética de Gilka, como também a sua própria história na ocasião em que disputava com Rosalina Coelho Lisboa e Prado Kelly, o prêmio de melhor poesia concedido pela Academia Brasileira de Letra. Pela primeira vez a ABL concedeu o prêmio a uma mulher, Rosalina, fato que foi considerado pela imprensa como uma "vitória do feminismo". Nos jornais que se manifestaram sobre a premiação, os julgamentos giravam entorno de estereótipos gênero, raça e classe, em que "no país das

\footnotetext{
${ }^{45}$ Cf:: GONZALEZ, 1988: p. 70.

${ }^{46}$ A relação entre poesia e musas atravessa a tradição Ocidental. Na Grécia Antiga, as musas eram as filhas da deusa Mnemosine (associada à memória), invocadas pelos poetas, como Hesíodo e Homero, para inspirálos na revelação da verdade. Sobre o tema, $C f$ : COSTA, 2017. Nos movimentos artísticos do período, a musa inspiradora girava entorno do arquétipo das mulheres fatais, as Salomés (Oliveira, 2005), que em Gilka ganhou outra significação - de maldita a vivificante.
} 
musas" (Revista Fon-Fon, 1921), Rosalina - de condição socioeconômica elevada - teria ganhado por ser mais bonita, refinada, elegante e erudita; já Gilka teria perdido por não ter "graça e elegância", por se vestir no "penúltimo figurino" e, ainda, por ser moradora dos subúrbios da cidade do Rio de Janeiro. Eis algumas opressões da colonialidade de gênero que interditaram a premiação de Gilka. Por "não ser bonita", premiá-la seria, segundo a Revista A.B.C., "um festival no tálamo, após o burguês 'jantar melhor' onde Rodolpho Machado, aedo e marido, recitaria uma ode anêmica - da sua musa pobre de hematias. A fealdade passaria mais a miúdo, gozando a celebridade aumentada. Nada Mais" (Revista A. B. C. 13. 08. 1921) ${ }^{47}$. Isto é, "no país das musas", Gilka Machado deixou de entrar para História do Brasil como a primeira mulher premiada pela Academia Brasileira de Letras por não se enquadrar no feminino gentrificado presente no imaginário de grande parte dos homens de letras. A menção à suposta anemia de Gilka, a sua falta de "hematias", pode se relacionar com a grande quantidade de pó que a poetisa usava no rosto $^{48}$. Machado sofreu intensos e constantes ataques do meio literário e jornalístico que não suportavam uma "escurinha" e "suburbana" como mulher de letras. Segundo Frantz Fanon, há um entrecruzamento entre o desenvolvimento de neuroses sóciopsíquicas e o racismo estrutural, pois, por meio da colonialidade do poder, o padrão de representação de si dominante é o do branco(a) europeu-europeia. Dessa forma, se compreende o porquê da busca pelo embranquecimento entre pessoas não brancas, gerando o que Fanon define como duplo narcisismo - o complexo de superioridade das pessoas brancas e o complexo de inferioridade das pessoas não brancas ${ }^{49}$; assim se compreende também as condições de possibilidade para o surgimento da originalidade transgressora das musas gilkanianas.

Enfim, apesar de ter sido embranquecida com o passar dos anos, assim como outro expoente da literatura brasileira (Machado de Assis) - embranquecimento este tão ativo que esta pesquisa chegou a ser posta em dúvida por certas práticas científicas epistemicidas ${ }^{50}$ que insistem em negar a afrodescendência de Gilka, bem como a validade

\footnotetext{
${ }^{47}$ Sobre a atuação e relação de Gilka Machado com a imprensa das primeiras décadas do século $\mathrm{XX}, C f$ : CARVALHO, 2018: p. 147-180.

${ }^{48}$ Cf.: CARAVALHO, 2018.

49 “A inferiorização é o correlato nativo da superiorização europeia. Precisamos ter a coragem de dizer: é o racista que cria o inferiorizado" (FANON, 2008: 90).

${ }^{50}$ Sobre o epistemicídio, Boaventura Santos e Maria Meneses, argumentam: “O mundo é um complexo mosaico multicultural. Todavia, ao longo da modernidade, a produção do conhecimento científico foi configurada por um único modelo epistemológico, como se o mundo fosse monocultural, que descontextualizou o conhecimento e impediu a emergência de outras formas de saber não redutíveis a esse paradigma. Assistiu-se, assim, a uma espécie de epistemicídio, ou seja, à destruição de algumas formas de saber locais, à inferiorização de outros, desperdiçando-se, em nome dos desígnios do colonialismo, a
} 
científica da epistemologia decolonial e do feminismo negro (práticas travestidas de alertas para os possíveis "riscos do anacronismo") -, em sua época o racismo estrutural da sociedade brasileira foi implacável em defini-la como "mestiça sombria", "pequena mulata", "feia cujas fotos enganam", entre outros termos racializados. Ou seja, este estudo comprova historicamente que o anacronismo está nos olhos de quem, diante da obra e vida de Gilka Machado, consegue a enxergar como "branca" - resulto de refinadas tecnologias de poder do racismo estrutural. Dessa forma, esta pesquisa tem o prazer de comprovar a interseccionalidade ${ }^{51}$ de opressões de gênero, raça e classe que atravessaram a existência de Gilka Machado, cuja vivência possibilitou a criação de uma escrita decolonial, uma poesia erótica de fronteira, que tornou imaginável (logo, possível) a musificação poética vivificante de mulheres negras e socioeconomicamente pobres da sociedade brasileira.

\section{Considerações Finais}

As potências pornô-eróticas de Gilka Machado mobilizam os poderes que o ficcional exerce na trama social - a Mulher Vivificante se confronta com a Mulher Gentrificada por acionarem diferentes imaginários, os quais, pela orientação ficcional, tornam-se manifestos, têm a possibilidade de materializarem-se no social-histórico instituído. O pornô-erótico é perturbador do ordenamento racional iluminista, no entanto, a entrada da autoria feminina em tal gênero literário transgride sua própria tradição por potencializar um novo feminino. Instauram um conflito - por um lado, a masculinidade ameaçada a condena e reprime; por outro, promove a formação de uma nova identidade feminina mobilizada pelo imaginário de igualdade de direitos entre homens e mulheres, pondo em discussão os direitos sexuais da mulher, ampliando sua cidadania. Os deslocamentos das tradicionais performances de gênero (BUTLER, 2016) de sua escrita são apropriados por feministas da Primeira República, as quais elegem sua pessoa e poesia como possibilitadora de um feminino feminista ${ }^{52}$. A escrita de Gilka Machado trouxe para a política a mobilização de afetos e paixões que instauraram um regime de

riqueza de perspectivas presente na diversidade cultural e nas multifacetadas visões do mundo por elas protagonizadas" (SANTOS, 2009: p. 183).

51 Lembrando que a interseccionalidade "é uma conceituação do problema que busca capturar as consequências estruturais e dinâmicas da interação entre dois ou mais eixos da subordinação. Ela trata especificamente da forma pela qual o racismo, o patriarcalismo, a opressão de classe e outros sistemas discriminatórios criam desigualdades básicas que estruturam as posições relativas de mulheres, raças, etnias, classes e outras." (CRENSHAW, 2002: 177.

52 Sobre as relações de Gilka Machado com o movimento feminista da Primeira República, Carvalho, 2018 : 149-182. 
tensão entre as potências pornô-eróticas masculinas e femininas. Faz vibrar a esfera política ao contestar um imaginário hegemônico, para dizer com Chatal Mouffe. Ela transgride os limites pré-determinados do que é ser uma mulher, transforma em claro/visível o lado obscuro/invisível da colonialidade de gênero, para falar com Maria Lugones; tornando imaginável - logo possível - outra composição de feminino: o vivificante.

A originalidade transgressora da escrita de Gilka Machado se entrecruza a singularidade de sua presença no meio literário de então. A interseccionalidade das opressões de gênero, raça e classe que atravessaram sua existência possibilitou a criação de uma poética altamente disruptiva à colonialidade de gênero. A diferença de sua condição subalterna potencializou uma sensibilidade poética diferenciada, uma escrita decolonial, a qual esse estudo tem o prazer de conferir legitimidade histórico-científica. A poesia de Gilka Machado instaura nas primeiras décadas do século XX outras representações sociais para mulheres negras e economicamente pobres, fundamentais para os processos de construção de si - das imagens de controle para autodefinições, para dialogar com Patricia Hill Collins. Vida e arte se entrecruzam na construção de uma poesia erótica de fronteira, trazendo para cena literária mulheres tradicionalmente silenciadas da História do Brasil ${ }^{53}$.

Data de submissão: $31 / 10 / 2019$

Data de aceite: 06/04/2020

\footnotetext{
${ }^{53}$ Dedico este artigo a Jardelina de Sousa Oliveira, a Jade, e a todes a existências que, em tempos de pandemia, nos ensinam como as tecnologias da colonialidade do poder continuam ativas e atuantes em nossos tempos, classificando quem "merece" ou não desfrutar do status de humanidade e cidadania proclamados pelas democracias burguesas Ocidentais.
} 


\section{Referências Bibliográficas}

ARAN, Márcia \& PEIXOTO JR, Carlos Augusto. Subversões do desejo: sobre gênero e subjetividade em Judith Butler. Cad. Pagu [online]. 2007, n.28, pp.129-147.

ARAÚJO, Gilberto. "Gilka Machado: corpo, verso e prosa." $4^{\circ}$ ciclo de conferências: A literatura de autoria feminina. Academia Brasileira de Letras, proferida em: 10. jun. 2014. Disponível em: https://www.youtube.com/watch?v=XKQp_li1cS4 Acesso em: 10. out. 2019.

BATALLER, Maria Alba Sargatal. O estudo da gentrificação. Revista Continentes (UFRRJ), ano 1, n. 1, 2012, pp. 9-37.

BORGHI, Rachele. O espaço à época do queer: contaminações queer na geografia francesa. Ponta Grossa: Revista Latino-americana de Geografia e Gênero, ago. / dez. 2015, v. 6, n. 2, p. 133 - 146.

BRASIL. "Código Penal da República", 1890. In: PIERANGELLI, José Henrique. Códigos Penais do Brasil: evolução histórica. São Paulo: Jolavi, 1980, p. 316.

BUTLER, Judith. Problemas de gênero: feminismo e subversão da identidade. $11^{\mathrm{a}}$ ed. Rio de Janeiro: Civilização Brasileira, 2016.

CARROLL, Noël. A filosofia do horror ou paradoxos do coração. Tradução de Roberto Leal Ferreira. Campinas, SP: Papirus Editora, 1999.

CARVALHO, Marina Vieira de. O chique em choque? Os malabaristas da subsistência do pós-abolição carioca. Rio de Janeiro: Multifoco, 2012.

CARVALHO, Marina Vieira de. Leituras do prazer: a criação pornô-erótica na alvorada da modernidade carioca. Tese de doutorado, IFCH /UERJ, Rio de Janeiro, 2018.

CASTORIADIS, Cornélius. A instituição imaginária da sociedade. Rio de Janeiro: Paz e Terra, 1982.

CERTEAU, Michel. A escrita da história. Rio de Janeiro: Forense Universitária, 2008.

COLLINS, Patricia Hill. O pensamento feminista negro: conhecimento, consciência e a política do empoderamento. São Paulo, Boitempo, 2019.

COSTA, Fabrício Lemos da . A Evolução do Pensamento Grego Antigo: da Inspiração das Musas à Cosmologia. Pólemos, v. 6, 2017, p. 83-97.

CRENSHAW, Kimberlé Williams. Documento para o encontro de especialistas em aspectos da discriminação racial relativos ao gênero. Revista Estudos Feministas 10, 2002.

DARNTON, Robert. “Sexo dá o que pensar”. In: NOVAES, Adauto (org.). Libertinos e Libertários. São Paulo: Companhia das Letras,1996, pp. 21-42.

EVARISTO, Conceição. 'Minha escrita é contaminada pela condição de mulher negra'. Nexo Jornal. 26 maio. 2017. Disponível em: 
https://www.nexojornal.com.br/entrevista/2017/05/26/Concei\%C3\%A7\%C3\%A3oEvaristo-\%E2\%80\%98minha-escrita-\%C3\%A9-contaminada-pelacondi\%C3\%A7\%C3\%A3o-de-mulher-negra\%E2\%80\%99 Acesso em: 22. out. 2019.

FANON, Frantz. Pele negra, máscaras brancas. Tradução: Renato da Silveira. Salvador: EDUFBA, 2008.

FERREIRA, Marcela Roberta Ferraro. Os desdobramentos de Salomé: leitura da poesia erótica de Gilka Machado. Dissertação de mestrado apresentada ao Instituto de Estudos da Linguagem da Universidade Estadual de Campinas, São Paulo, 2002.

FRY, Peter. “'Feijoada' e 'Soul Food': notas sobre a manipulação de símbolos étnicos e nacionais". In: Para Inglês Ver - identidade e política na cultura brasileira. Rio de Janeiro: Zahar, 1982.

GAY, Peter. A experiência burguesa da Rainha Vitória a Freud: a educação dos sentidos. São Paulo: Companhia das Letras, 1988.

GIACOMINI, Sonia Maria. Beleza Mulata e Beleza Negra. Revista Estudos Feministas, n especial: Colóquio Internacional Brasil, França e Quebec, 1994.

GOMBRICH, Ernst. Arte e Ilusão: um estudo da psicologia da representação pictórica. São Paulo: Martins Fontes, 1995.

GONZALEZ, Lélia. A categoria político-cultural de amefricanidade. Tempo Brasileiro, Rio de Janeiro, n. 92/93, 1988.

GROSFOGUEL, Jamon \& JOAZE, Bernardino. Decolonialidade e perspectiva negra. Revista Sociedade e Estado. vol.31 no.1 Brasília, 2016.

HALL, Stuart. “Quem precisa da identidade?” In: SILVA, Tomaz Tadeu da (Org.). Identidade e diferença: a perspectiva dos estudos culturais. Trad. de Tomaz Tadeu da Silva. Petrópolis: Vozes, 2009, p. 103-133.

ISER, Wolfgang. O Fictício e o Imaginário: perspectivas de uma antropologia literária. Rio de Janeiro: EdUerj, 2013.

LAQUEUR, Thomas. Inventando o sexo dos gregos à Freud. Rio de Janeiro, Relume Dumará, 2001.

LUGONES, María. Colonialidad y género. Tabula Rasa. Bogotá, No.9,2008, p. 73-101.

LUGONES, Maria. Rumo a um feminismo descolonial. Revista Estudos Feministas.v. 22, n. 3, 2014. 
MACHADO, Gilka. Poesia completa. São Paulo: V. de Moura Mendonça - Livros, 2017.

MAIA, João da. Para tudo, um sorriso (no país das musas). Revista Fon-Fon!. Rio de Janeiro, 13 ago. 1921.

MALUF, Marina; MOTT, Maria Lúcia. "Recônditos do mundo feminino". In: NOVAIS, Fernando; SEVCENKO, Nicolau (Org.). História da vida privada no Brasil, vl. 3: República: da belle époque à era do rádio. São Paulo: Companhia das Letras, 1998. p. 368-422.

MOUFFE, Chantal. Sobre o político. São Paulo: Martins Fontes, 2015.

MURICY, José Cândido de Andrade. Panorama do Movimento Simbolista Brasileiro. $2^{a}$ Ed. Brasília: Conselho Federal de Cultura e Instituto Nacional do Livro, 1973.

OLIVEIRA, Cláudia de. As Pérfidas Salomés: o ideal feminino simbolista e a representação da mulher urbana nas ilustradas Fon-Fon! e Para Todos - 1900-1930. XXIX Encontro annual da ANPOCS. 2005.

Revista A.B.C. O Julgamento de Phrynéa. Rio de Janeiro, 13 ago. 1921.

RIOS, Ana Maria; MATTOS, Hebe Maria. O pós-abolição como problema histórico: balanços e perspectivas. Topoi (Rio J.), Rio de Janeiro, v. 5, n. 8, 2004, p. 170-198.

SANTOS, Boaventura de Sousa; MENESES, Maria Paula (orgs.). Epistemologias do Sul. Coimbra: Almedina, 2009.

SOLIVA, Thiago Barcelos. Uma cultura dos contatos: sexualidades e erotismo em duas obras de Gilberto Freyre. Bagoas - estudos gays: gênero e sexualidades. v. 6, n. 07, 2012. 